\title{
Anticancer Activities of Protopanaxadiol- and Protopanaxatriol-Type Ginsenosides and Their Metabolites
}

\author{
Xiao-Jia Chen, ${ }^{1}$ Xiao-Jing Zhang, ${ }^{1}$ Yan-Mei Shui, ${ }^{2}$ Jian-Bo Wan, ${ }^{1}$ and Jian-Li Gao ${ }^{2}$ \\ ${ }^{1}$ State Key Laboratory of Quality Research in Chinese Medicine, Institute of Chinese Medical Sciences, University of Macau, Macau \\ ${ }^{2}$ Zhejiang Chinese Medical University, Hangzhou, Zhejiang 310053, China
}

Correspondence should be addressed to Jian-Bo Wan; jbwan@umac.mo and Jian-Li Gao; jianligao@gmail.com

Received 17 March 2016; Accepted 27 April 2016

Academic Editor: Ki-Wan Oh

Copyright (c) 2016 Xiao-Jia Chen et al. This is an open access article distributed under the Creative Commons Attribution License, which permits unrestricted use, distribution, and reproduction in any medium, provided the original work is properly cited.

\begin{abstract}
Recently, most anticancer drugs are derived from natural resources such as marine, microbial, and botanical sources, but the low success rates of chemotherapies and the development of multidrug resistance emphasize the importance of discovering new compounds that are both safe and effective against cancer. Ginseng types, including Asian ginseng, American ginseng, and notoginseng, have been used traditionally to treat various diseases, due to their immunomodulatory, neuroprotective, antioxidative, and antitumor activities. Accumulating reports have shown that ginsenosides, the major active component of ginseng, were helpful for tumor treatment. 20(S)-Protopanaxadiol (PDS) and 20(S)-protopanaxatriol saponins (PTS) are two characteristic types of triterpenoid saponins in ginsenosides. PTS holds capacity to interfere with crucial metabolism, while PDS could affect cell cycle distribution and prodeath signaling. This review aims at providing an overview of PTS and PDS, as well as their metabolites, regarding their different anticancer effects with the proposal that these compounds might be potent additions to the current chemotherapeutic strategy against cancer.
\end{abstract}

\section{Introduction}

Cancer is a group of diseases characterized by evading growth suppressors, activating invasion and metastasis, avoiding immune destruction, and deregulating cellular anabolism and metabolism. In 2015, a total of 1,658,370 new cancer cases and 589,430 cancer deaths were projected to occur in the United States [1]. In China, the estimates of new cancer incident cases and cancer deaths were 3,372,175 and $2,113,048$, respectively [2]. However, chemotherapy always suffered from increasing multidrug resistance. Thus, identifying more chemicals extracted from herbal medicines is an essential step in advancing cancer treatment. Nowadays, many herbs, typically ginseng and notoginseng, have been used in clinical practice to treat advanced cancer in eastern countries, and researchers pay more and more attention to the potential therapeutic effects of those herbs. Therefore, it is very important to understand the bioactive effects and mechanism of the main ingredients and absorbed metabolites of these herbs.
Asian ginseng, American ginseng, and notoginseng, the roots and rhizome of Panax ginseng C. A. Meyer, Panax quinquefolius L., and Panax notoginseng (Burk.) F. H. Chen, belong to genus Panax of the family Araliaceae. These herbs have long been used for preventive and therapeutic purposes for thousands of years in Asian and North American countries. Ben Cao Gang Mu recorded that Asian ginseng was usually used as a tonic, sedative, life-prolonging, or gastrointestinal regulation drug to treat fatigue, blood deficiency, insomnia, and impotence [3]. American ginseng was first recorded in Ben Cao Cong Xin in 1757 and was used for relieving internal heat, cough, bloody phlegm, dysphoria and tiredness, and dry and thirsty mouth and throat. Notoginseng, another herb belonging to the genus Panax, is well known for treatment of blood disorders. Notoginseng is usually available in two different forms: the raw and steamed (processed) forms. The raw notoginseng has been traditionally used for its hemostatic and cardiovascular effects to arrest internal and external bleeding, reduce swelling and pain, and remove blood stasis and promote blood circulation [4]. 
Unlike raw notoginseng, the steamed form has been widely accepted to be a tonic to "nourish" the blood and to increase blood cells in anemic conditions [5].

Modern studies showed that Asian ginseng, American ginseng, and notoginseng exhibited various significant pharmacological effects, and the anticancer activities of ginseng types have been extensively investigated based on the functional capacity of inhibiting cancer cell growth, inducing angiogenesis, delaying invasion and metastasis, and regulating tumor-related immune suppression by their active ingredients, ginsenosides and their metabolites [6, 7]. PDS (20(S)-protopanaxadiol (PPD) saponins) and PTS (20(S)protopanaxatriol (PPT) saponins) and their metabolites are the major anticancer active components of the most popular Panax herbs. Notably, ginsenoside Rg3 was produced as an antiangiogenic drug in China. In this review, we summarize and compare the regulatory effects of different ginsenosides and their metabolites on the development of cancer, and the corresponding mechanisms have also been discussed.

\section{Chemical Structures and Metabolism of PDS and PTS}

Saponins and sapogenins of ginseng types (also named ginsenosides) are the major bioactive constituents which were possibly responsible for the comparable and distinct pharmacological activities in the three Panax herbs [8]. All of the total ginsenosides extracts of these three herbs are chemical mixtures containing a group of triterpene glycosides with similar ingredients and structure, which have been shown to possess anticancer, anti-inflammatory, and neuroprotective activities and promote blood circulation to treat cardiocerebrovascular diseases [9]. Nowadays, more than sixty individual saponins were isolated from these three Panax herbs. They are classified into two main groups according to the different aglycone, namely, PDS, such as ginsenoside Rb1, and PTS, such as ginsenoside Rg1. The two types of triterpenoid saponins showed diverse or even antagonistic pharmacological activities [10]. Cumulated researches elucidated that the content of total saponins in notoginseng is higher than those in Asian ginseng [11], while ginsenosides $\mathrm{Rb} 1, \mathrm{Re}$, and Rgl are enriched in American ginseng, and ginsenosides $\mathrm{Rf}$ and $\mathrm{Rb} 2$ are enriched in Asian ginseng [12].

It is noteworthy that PDS and PTS are not easily absorbed by the body through the intestines due to their hydrophilicity [13]. Little amount of PDS could be absorbed in the gastrointestinal tract following oral intake. Therefore, these constituents inevitably come into contact with and are metabolized by microflora in the alimentary tract. As shown in Figure 1, upon oral consumption, ginsenosides are partly transformed into the PPD and PPT through a series of deglycosylation procedures by acid hydrolysis and intestinal bacterial actions [14]. All of the metabolites, such as compound $\mathrm{K}(\mathrm{CK}), \mathrm{PPD}$, and $\mathrm{PPT}$, are nonpolar compared to the parental components ginsenosides, which could be easily absorbed in the gastrointestinal tract and express biological actions [15]. The ability of PPD to be absorbed after oral administration had been demonstrated through pharmacokinetic studies. It was shown that PPD accumulated largely in the stomach (44\%) and small in the intestine (32\%) and was also present in the brain $(0.01 \%)$ [16].

Many reports reveal that the metabolites were assessed as more potent bioactive ingredients than the natural ones. It is validated that PPD, a stable deglycosylated PDS metabolic derivative that could be formulated for oral gavage, exerted antineoplastic actions, which were more effective than its prototype [17]. A good example is the improved antiandrogen-independent prostate cancer activity exerted by the intestinal bacterial metabolites compared to natural occurring ginsenosides, through decreasing survival rate, inhibiting proliferation, inducing apoptosis, and leading to cell cycle arrest in PC-3 cells [18]. The increase of lipotropy and decrease of C-6 steric hindrance, which were caused by deglycosylation by intestinal bacteria, might be the reason for the higher activity of metabolites.

\section{Anticancer Effects of Ginsenosides}

Preclinical and clinical researches demonstrated that ginsenosides have cancer preventing activities to various tumors, including gastric carcinoma, breast cancer, liver cancer, ovarian cancer, colon cancer, melanoma, and leukemia [19]. Extensive phytochemical and pharmacological studies on ginseng and notoginseng proved that the PDS and PTS are the main anticancer compositions and that the activities of PDS were more powerful than those of PTS $[15,20,21]$. In general, the anticancer effects of total ginsenoside from Asian ginseng and American ginseng, but not notoginseng, are widely reported; meanwhile, lots of publications indicated the anticancer effects of many pure ginsenosides, such as ginsenosides Rg3 and Rh2, isolated from all of the three ginseng types. In view of the results reported by Lee et al. [20] and Jin et al. [21], the relative nonpolar and PDS class ginsenosides exhibited more cytotoxicity on breast cancer cells and efficient cellular uptake on MCF-7 and MCF-7/MX cells compared with the relative polar and PTS class compounds. Shim et al. [15] suggested that the PDS and ginsenosides Rd, Rg3, Rk1, $\mathrm{Rg} 5$, and Rh2 showed potent or moderate inhibitory activities on inducing apoptosis of cancer cells through activating the caspase-3 pathway, whereas the PTS and ginsenosides Rf, Rg1, Re, Rh1, and Rg2 did not exhibit any inhibitory activity.

The structure-activity relationships indicated that both glycosylation at $\mathrm{C}-3-\mathrm{OH}$ and nonoxidation at C-6 on ginsenosides might be important for the inhibition of the chymotrypsin-like activity of the $20 \mathrm{~S}$ proteasome which plays an important role in selective protein degradation and regulates cellular events in anticancer process. On the other hand, several results indicate compound with less polar chemical structures possesses higher cytotoxic activity towards cancer cells. The ginsenosides with two molecules of glucose linked to $\mathrm{C}-3-\mathrm{OH}$ have a less potent inhibitory activity than those with one molecule; for example, Rh2 (one glucose at C-3) showed more potent pharmacological activities than Rg3 (two types of glucose at C-3) [7]. From this perspective, cytotoxic potencies of the hydrolysates of PDS and PTS, especially PPD and CK (the hydrolysate of PPD-type ginsenoside fractions), are much stronger than the original ginsenosides. 


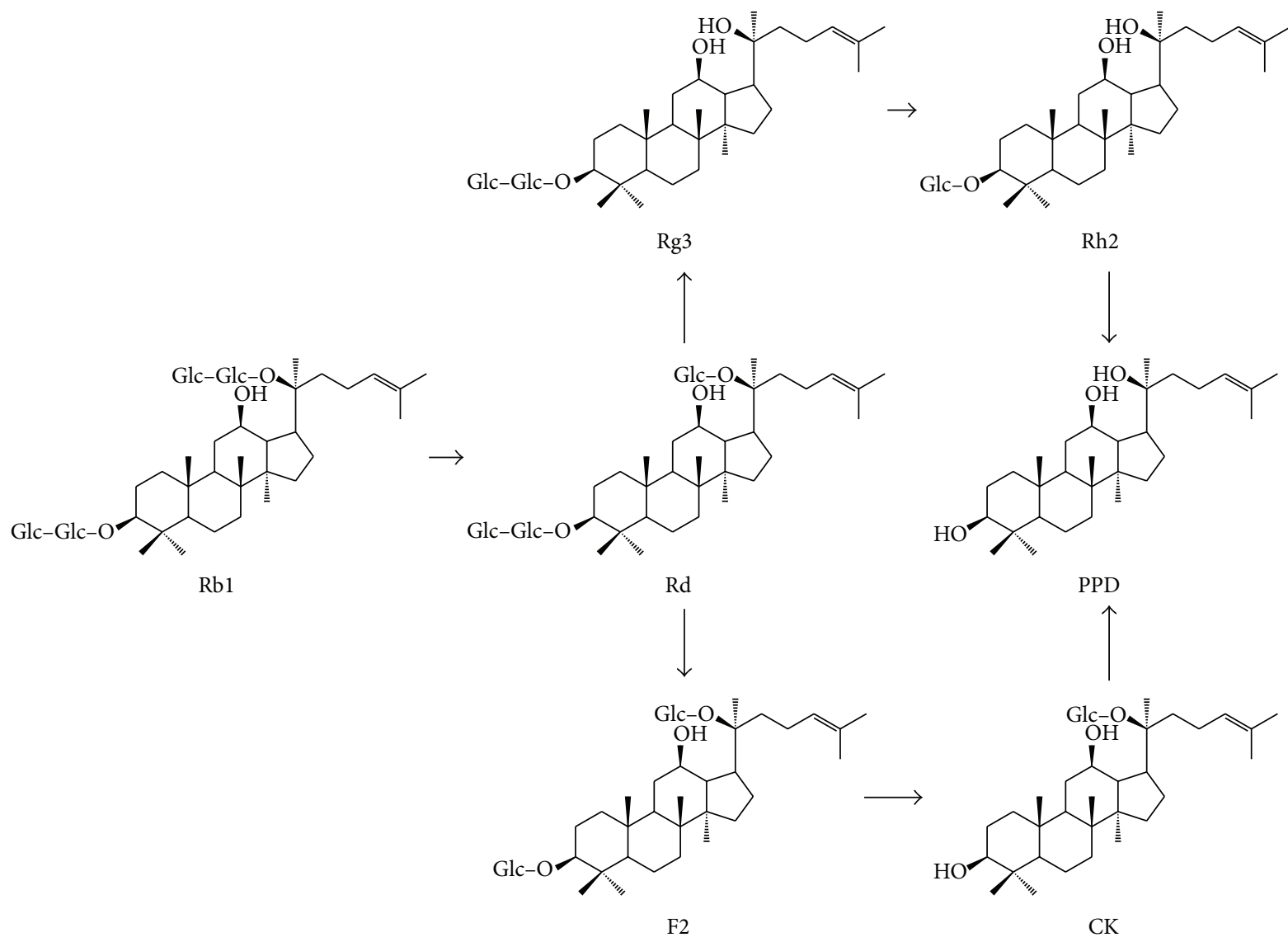

(a)

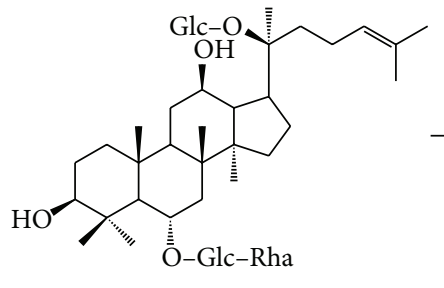

$\mathrm{Re}$<smiles>C1=CC=C1</smiles>

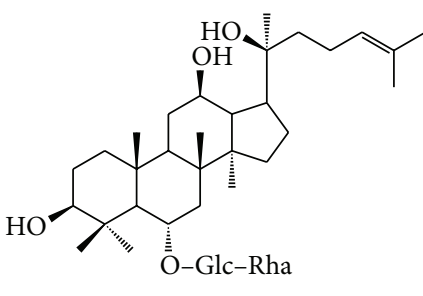

$\operatorname{Rg} 2$

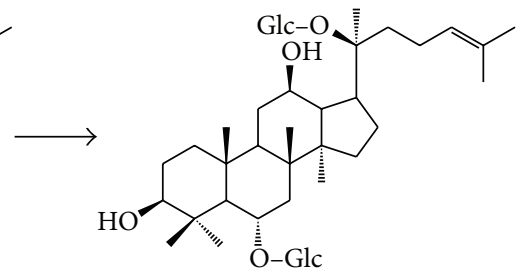

$\operatorname{Rg} 1$
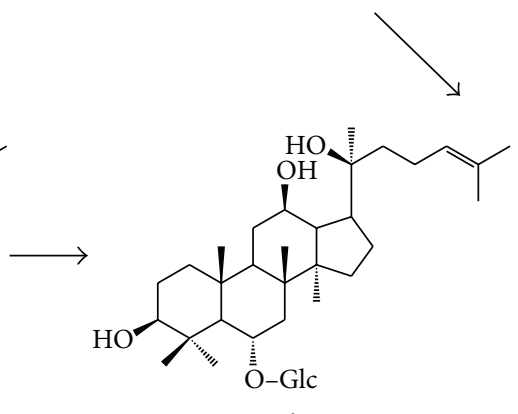

Rh1<smiles>CC(C)=CCC[C@](C)(O)C1CC[C@]2(C)C1[C@@H](O)C[C@H]1C(C)(C)[C@@H](O)CCC12C</smiles>

PPT

Or

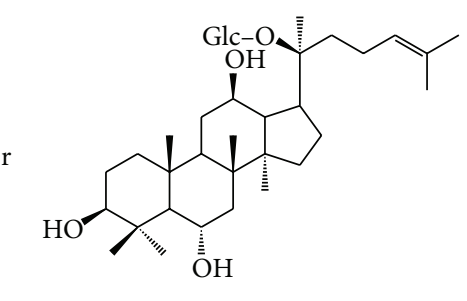

F1

(b)

FIgURE 1: Major metabolic processes of (a) 20(S)-protopanaxadiol- and (b) 20(S)-protopanaxatriol-type saponins. CK: compound K, PPD: 20(S)-protopanaxadiol, and PPT: 20(S)-protopanaxatriol. 


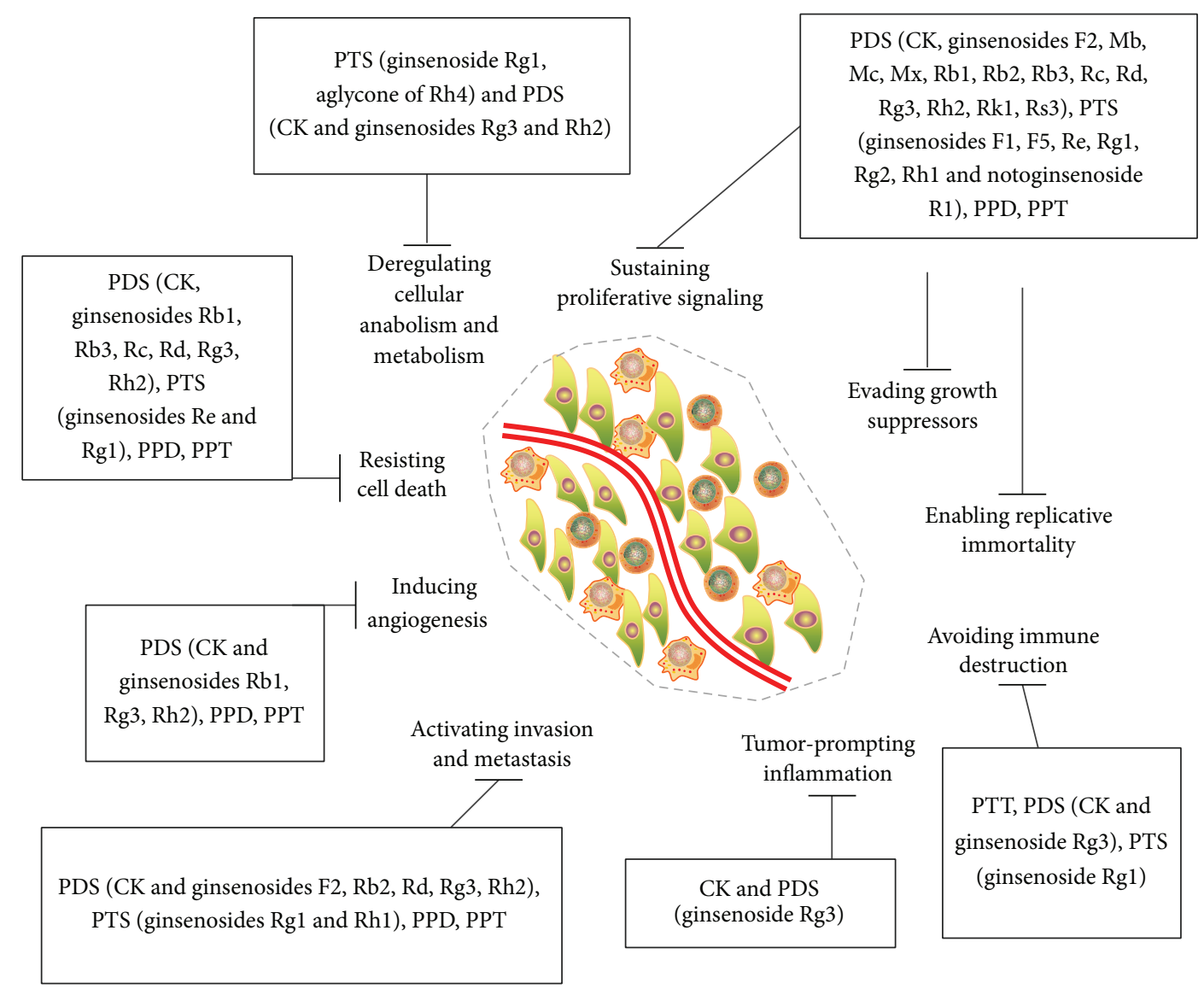

FIGURE 2: Therapeutic targets of ginsenosides on cancer. PTS: 20(S)-protopanaxadiol saponins, PDS: 20(S)-protopanaxatriol saponins, PPT: protopanaxatriol, PPD: protopanaxadiol, and CK: compound K.

It appears that CK, Rh2, Rg3, PPD, and PPT are possibly responsible for the enhanced anticancer activity of ginseng. In fact, processing of herbs could change the chromatographic and pharmacological profiles of notoginseng and cause an increase of PDS and its hydrolysates, including ginsenosides $\mathrm{Rh} 2$, Rk1, Rk3, and Rg3, which might contribute to the greater antiproliferative effects against liver cancer cells, SNU449, SNU182, and HepG2 of steamed notoginseng than its raw form [22]. In another case, Lin et al. [23] attested that, after lactic acid bacteria fermentation, antihepatocarcinoma activity of notoginseng was improved, along with the fact that notoginsenoside R1 and ginsenosides Rgl, Rbl, Rd, and $\mathrm{Rh} 4$ were decreased, while ginsenosides Rh1 and Rg3 were increased during fermentation. Additionally, after it is orally taken, PTS would be inevitably deglycosylated by intestinal bacteria. For instance, biotransformation of ginsenoside Rg1 by the fungus Absidia coerulea AS3.2462 yielded five metabolites. Three of them exhibited moderate reversal activity towards A549/taxol MDR tumor cells in vitro [24]. The therapeutic targets of ginsenosides on cancer were summarized in Figure 2.

3.1. Inhibiting Cancer Cell Growth. Extensive experiment data indicates that ginsenosides could inhibit tumor growth by inhibiting cancer cell proliferation, which can be related with inducing apoptosis and autophage of cancer cells, inhibiting proliferative signaling pathways, or regulating the activity of tumor suppressors. For instance, ginsenoside Rhl showed great estrogenic effect in human breast carcinoma MCF-7 cells [25]. The synthesized monoester of ginsenoside Rh1 showed moderate effects on murine $\mathrm{H} 22$ hepatoma cells [26]. Yang et al. [27] suggested that ginsenoside Rd could serve as a lead to develop novel chemotherapeutic or chemopreventive agents against human cervical cancer.

\subsubsection{Inducing Apoptosis and Autophage of Cancer Cells}

(1) PPD. Nowadays, PPD has been well characterized to possess the pleiotropic anticarcinogenesis capabilities in many cancer cell lines, including A172, A549, B16, Caco-2, Ehrlich ascites cells L1210, H1299, H358, H838, HCT-116, HCT-8, HeLa, HepG2, HPAC, Int-407, Jurkat, LNCaP, MCF-7, MDAMB-468, Me180, Molt-4, Panc-1, P388, PC3, Raji, SK-HEP-1, SW-480, T98G, and THP-1. PPD could induce different forms of programmed cell death, including typical apoptosis and autophagy through both caspase-dependent and caspaseindependent mechanisms, which could be testified in models of two human glioma cell lines, SF188 and U87MG. For the SF188 cells, PPD activated caspase-3, caspase-7, caspase-8, and caspase- 9 and induced rapid apoptosis. Interestingly, in 
U87MG cells PPD induces cell death without activating any caspases, but with promoting the dramatic autophagy of cells [28]. Additionally, PPD induced the intrinsic and extrinsic apoptotic pathways, activated death receptor 5 and caspase-3, caspase- 8 , and caspase- 9 , and upregulated the mRNA and/or protein levels of endoplasmic reticulum stress-associated molecules in HepG2 cells [29]. The research reported by Popovich and Kitts [30] showed that PPD possessed characteristic effects on the proliferation of human leukemia cells THP- 1 and that the presence of sugars in PPD aglycone structures reduced the potency to induce apoptosis. It could also inhibit the growth of acute lymphoblastic leukemia (ALL) cell lines Reh and RS411 cells by stimulating differentiation and inhibiting growth and cell cycle progression of ALL cells without changing cell apoptosis [31].

The analogue of PPD is now also known to be helpful for tumor treatment. 20(S)-25-Methoxyl-dammarane$3 \beta, 12 \beta, 20$-triol $\left(25-\mathrm{OCH}_{3}-\mathrm{PPD}\right)$ is a dammarane-type triterpene sapogenin isolated from $P$. notoginseng, which has been regarded as the principal medicinal component of the plant and has shown anticancer effects in vitro and in vivo with a low toxicity to noncancer cells [32]. Bi et al. [33] added it to LS174, SW620, SW480, and A549 cells and demonstrated that it significantly inhibited cell proliferation and induced apoptosis by modulation on $\beta$-catenin, a key mediator in the Wnt pathway. Meanwhile, other researchers found that 25- $\mathrm{OCH}_{3}-\mathrm{PPD}$ exhibited activity against human $\mathrm{H} 358$ and H838 lung cancer cells and androgen-dependent prostate cancer cells, LNCaP and PC3, through decreasing survival, inhibiting proliferation, and inducing apoptosis and $\mathrm{G}_{1}$ cell cycle arrest. This compound also decreased the levels of cell proliferation-associated proteins (MDM2, E2F1, cyclin D1, and cyclin-dependent kinase 2 (CDK2) and CDK4) and increased the activation of proapoptotic proteins (cleaved PARP, cleaved caspase- 3 , caspase- 8 , and caspase-9) [32]. Wu et al. [34] detected that $25-\mathrm{OCH}_{3}-\mathrm{PPD}$ produced a significant inhibitory effect on activated t-HSC/Cl- 6 cells based on its regulatory function to increase the level of cellular GSH and cleaved caspase-3, while PPT, Rg3, Rb1, Rb3, Rg1, Rg2, and Re showed little or no cytotoxic effects. Aside from 25$\mathrm{OCH}_{3}$-PPD, $20(R)$-dammarane-3 $\beta, 12 \beta, 20,25$-tetrol (25-OHPPD) has abilities to inhibit proliferation, leading to cycle arrest, inducing apoptosis on cancer cells, and inhibiting the growth of xenograft tumors without any host toxicity [35].

(2) CK. 20-O-D-Glucopyranosyl-20(S)-protopanaxadiol (CK, IH-901, or M1), one of the most important metabolites of PDS by intestinal microorganisms, is drawing increasing attention recently due to its potent inhibitory benefits on cancer, including hepatocarcinoma cells, breast cancer cells, lymphoma cells, and melanoma cells, in vitro and in vivo (shown in Table 1) [36]. The $\mathrm{IC}_{50}$ of $\mathrm{CK}$ to inhibit the proliferation was $12.7,11.4,8.5$, and $9.7 \mu \mathrm{M}$ for B16-BL6, HepG2, K562, and 95-D cell lines, respectively [37]. Oral administration of CK significantly inhibited the tumor proliferation at the implantation site after intrapulmonary implantation of Lewis lung carcinoma and colon 26-L5 tumor cells in concentration- and time-dependent manners and suppressed the metastasis to meditational lymph nodes, which was primarily due to induce caspase-3-dependent apoptosis [38]. Moreover, the analogue of CK, 3-O-oleoyl CK (OCK), caused 2.6-fold suppression of tumor growth compared with CK on the growth and metastasis of murine B16-F10 melanoma cells in C57BL/6 mice [39].

CK exhibits cytotoxicity largely by inducing apoptosis via generation of reactive oxygen species (ROS), regulating on cell cycle arrest at the $G_{1}$ phase, upregulating Bax, disrupting the mitochondrial membrane potential, activating caspase3 , caspase- 8 , and caspase- 9 , inhibiting of telomerase activity, and decreasing cyclooxygenase-2 (COX-2) expression and prostaglandin $\mathrm{E}_{2}\left(\mathrm{PGE}_{2}\right)$ levels via an $\mathrm{AMP}$-activated protein kinase- (AMPK-) dependent pathway [40]. The treatment of MDA-MB-231 with CK upregulated COX-2 mRNA and protein and enhanced the production of $\mathrm{PGE}_{2}$ [41]. Hu et al. [42] and Cho et al. [43] reported that CK significantly inhibits the viabilities of BGC823, SGC7901, and HL-60 cells in doseand time-dependent manners mainly through mitochondriamediated internal pathway. In the HL-60 treatment, this compound still induced a series of intracellular events associated with death receptor-dependent apoptotic pathway [43].

Meanwhile, CK led to $G_{1}$ cell cycle arrest in tumor cells. Exposure to CK for 48 hours led to $\mathrm{G}_{1}$ arrest in Hep3B, U937 cells, MDA-MB-231, Hs578T, and MKN28 cells [40, 41, 44]. The CK-mediated $G_{1}$ arrest resulted from an increase in p2 $7^{\text {Kipl }}$ mRNA and protein expression followed by a decrease in CDK2 kinase activity. Saiki [45] proposed that the induction of apoptosis of tumor cells by CK involved the upregulation of the CDK inhibitor $\mathrm{p} 27^{\mathrm{Kip} 1}$ as well as the downregulation of c-Myc and cyclin D1 in a time-dependent manner.

In addition to PPD and $\mathrm{CK}, \mathrm{Rh} 2$ and $\mathrm{Rg} 3$ may be also effective preclinical candidate compounds for liver cancer, breast cancer, prostatic cancer, pediatric acute myeloid leukemia and glioblastoma, and so forth (shown in Table 1). $\mathrm{X}$. Wang and Y. Wang indicated that Rh2 significantly prolonged the survival of mice with pediatric leukemia and induced apoptosis of leukemia cells through miR-21modulated suppression of Bcl-2 [46]. Liu et al. found that $\mathrm{Rh} 2$ dose-dependently reduced SCC viability and increased autophagy and reduced $\beta$-catenin signaling in SCC cells [47].

3.1.2. Inhibiting Proliferative Signaling Pathways. Besides the activities mentioned above, PPD and CK can exert their anticancer effect through direct antiproliferation activation. In fact, our results suggest that the anticancer activity of PPD in colon cancer cells may be mediated through targeting multiple cancer signaling pathways, namely, nuclear factorkappa B (NF- $\kappa$ B), JNK, and mitogen-activated protein kinase (MAPK)/extracellular signal-regulated kinase (ERK) signaling pathways [48]. Hwang et al. [49] also demonstrated the antiproliferative and proapoptotic effects of an enzymatically fortified ginseng extract on KATO3 cells appear to be associated with the upregulation of Bax, the activation of NF- $\kappa$ B, and the inhibition of mTOR and PKB signals. PPD also downregulates the PI3K/Akt signaling pathway in A549 cells [50]. Yu et al. [51] found that PPD inhibited estrogen-stimulated gene expression and cell proliferation both in vitro and in vivo through blocking $\left[{ }^{3} \mathrm{H}\right]-17-\beta$-estradiol- $\left(\mathrm{E}_{2}-\right)$ induced 
transcriptional activation and inhibiting colony formation of endometrial cancer cells. Kang et al. described the fact that CK induced the activation of c-Jun N-terminal kinase (JNK) and the transcription factor AP-1, a downstream target of JNK [44]. Furthermore, CK induced apoptosis and inhibits fibroblast growth factor receptor 3 (FGFR3) expression and signaling in myeloma cell line KMS-11, suggesting candidacy for the chemoprevention and the treatment of myeloma [52].

CK also depresses several cell proliferation signaling pathways, for example, ERK, Janus activated kinase (JAK) 1/signal transducer and activator of transcription 3 (STAT3), AMPK pathway, and FGFR3 signaling. The treatment of MDA-MB-231 with CK upregulated COX-2 mRNA and protein, enhanced the production of $\mathrm{PGE}_{2}$, and induced the sustained activation of ERK [41]. Furthermore, CK inhibited phosphorylation of STAT3 and its upstream activator, JAK1, but not JAK2, downregulated STAT3 target genes bcl- $\mathrm{x}_{\mathrm{L}}$, bcl2, survivin, cyclin E, and D1, and enhanced the expression of protein tyrosine phosphatase SHP-1, but not phosphatase and tensin homolog (PTEN) in this treatment [53].

Similar to PPD and CK, other PDS also target in the cancer cell proliferation related signaling pathways. For example, our results strongly suggest that ginsenoside $\mathrm{Rg} 3$ diminishes nuclear staining intensity of $\beta$-catenin; the anticancer activity of $\operatorname{Rg} 3$ may be in part caused by blocking the nuclear translocation of $\beta$-catenin in colon cancer cells [54]. Besides, treatment with ginsenoside $\mathrm{Rd}$ dose- and time-dependently inhibited the migration and invasion of human hepatocellular carcinoma HepG2, Hep3B, SNU-398, and SNU-878 cells via blocking MAPK signaling, inhibiting the phosphorylation of ERK and p38 MAPK, inhibiting AP-1 activation [55].

3.1.3. Regulating the Activity of Tumor Suppressors. Tumor suppressor, such as p53, VHL, ING4, Rb, PTEN, p16, p21, APC, DCC, NF1, NF2, WT1, and DR4 death receptor, is a type of genes that protects a cell from one step on the path to cancer [56]. Defects in the tumor suppressor pathway make tumors vulnerable to varieties of stresses, which can be exploited therapeutically. CK inhibits HCT-116, SW-480, and HT-29 cancer cell growth by upregulation of p53/p21, FoxO3a-p27/p15, and Smad3 and downregulation of cdc25A, CDK4/CDK6, and cyclin D1/3 [57]. Similarly, PPD could activate p53 and p21 and downregulate the levels of CDK2, cyclin E and cyclin D1, and PCNA in NIH3T3 cells [58].

As shown in Table 1, several other PDS, such as ginsenosides $\mathrm{Rg} 3, \mathrm{Rh} 2, \mathrm{Rk} 1$, and Rs3, also demonstrated activation of the activity of p53 and p21 [59]. Rs3 could elevate the protein levels of $\mathrm{p} 53$ and $\mathrm{p} 21^{\mathrm{WAF} 1}$ and then downregulate the activities of the cyclin-dependent kinases in SK-HEP1 cells [60]. Sin et al. indicated that $\mathrm{Rg} 3$ could induce senescence-like growth arrest by regulating Akt and p53/p21dependent signaling pathways in human glioma cells [61]. Rg3-mediated phosphorylation of p53 resulted in inhibition of Akt phosphorylation, which in turn reduced MDM2mediated p53 degradation [62]. Rg3 also has antiproliferative activity against melanoma by decreasing HDAC3 and increasing acetylation of $\mathrm{p} 53$ on lysine $(\mathrm{k} 373 / \mathrm{k} 382)$ both in vitro and in vivo [63]. Moreover, Rh2 induces apoptosis and paraptosis-like cell death in colorectal cancer cells through activation of p53 [64] and increases the expression level of DR4 death receptor [65]. Guo et al. [66] found that significant increases in Fas expression and caspase- 8 activity temporally coincided with an increase in p53 expression in p53nonmutated HeLa and SK-HEP-1 cells upon Rh2 treatment.

3.2. Antiangiogenesis. Tumor-induced angiogenesis (neovascularization) is one of the most important events concerning tumor growth and metastasis [45]. As shown in Tables 1 and 2, PPT, PPD, and several PDS, namely, CK, Rg3, Rh2, Rb1, and F2, presented significantly antiangiogenic effect. Through investigating their antiangiogenic effects in an angiogenesis model of human umbilical vein endothelial cells (HUVECs), Usami et al. [67] found that PPD displayed inhibition on proliferative activity of HUVECs in a dose-dependent manner and had potential as anticancer drug candidates.

Jeong et al. [68] investigated the antiangiogenic activity and relative mechanisms of CK in HUVECs. The outcomes revealed that CK significantly inhibited the proliferation and downregulated phosphorylation of p38 MAPK and AKT in bFGF treated HUVECs. Besides, it inhibited the migration and tube formation, reduced secreted level of vascular endothelial growth factor (VEGF), and increased the secreted level of pigment epithelium-derived factor (PEDF) at noncytotoxic concentrations. In vivo experimental results revealed that CK effectively disrupted bFGF-induced neovascularization in the Matrigel plugs excised from mice and inhibited the tumor formation of SGC7901 cells in nude mice [42, 68].

Recently, 20(S)-ginsenoside $\mathrm{Rg} 3$ was produced as a new anticancer drug in China due to its antiangiogenic effect. Clinical studies show that Rg3, especially in combination with chemotherapy, can reduce chemotherapy side effect and improve life quality and survival rates of patients with non-small cell lung cancer [171], gastric cancer [172], esophageal cancer [173], and so forth. The mechanism might be correlated with antitumor angiogenesis and improving the immune function. The results were confirmed in many animal models, such as C57BL/6 mice bearing Lewis lung tumor model and rabbits inoculated with liver VX2 tumor model. Yu et al. found that Rg3 could suppress the tumor growth and angiogenesis in VX2 transplanted hepatic tumor model in experimental rabbits. The tumor microvessel density (MVD) and the expression of VEGF were significantly lower than those of the control group [174]. Rg3 also enhanced the antiangiogenic of capecitabine in a model of BALB/c mice inoculated with $4 \mathrm{~T} 1$ breast cancer [175] and inhibited neovascularization and growth of mouse Lewis lung carcinoma with gemcitabine in C57BL/6 mice inoculated with Lewis lung carcinoma [176].

3.3. Delaying Invasion and Metastasis. Besides the activities mentioned above, some compounds belong to PDS and PTS also exert other pharmacological effects about anticancer. PDS and its metabolites, including Rb2, Rd, F2, Rh2, Rg3, $\mathrm{CK}$, and PPD, could inhibit the tumor invasion and metastasis. Moreover, PTS (shown in Table 2) and its metabolites, including Rg1, Rh1, and PPT, also affect the tumor invasion and metastasis process. Inhibiting epithelial-mesenchymal transition (EMT) and regulating the expression and activity 
TABLE 1: Summary of the anticancer activities of PPD and PDS.

\begin{tabular}{|c|c|c|}
\hline Compounds & Activities & Mechanisms \\
\hline \multirow[t]{5}{*}{$\begin{array}{l}\text { Protopanaxadiol } \\
(\mathrm{PPD})\end{array}$} & Antiproliferation & $\begin{array}{l}\mathrm{G}_{1} \text { phase arrest; promotes melanin production and increases DNA binding sites on the } \\
\text { cell surface and cell adhesiveness [69]; stimulates differentiation [31]; induces } \\
\text { caspase-dependent apoptosis [70]; activates NF- } \kappa \text { B signaling [71]; downregulates } \\
\text { PI3K/Akt signaling pathway [50] }\end{array}$ \\
\hline & $\begin{array}{l}\text { Inhibit tumor } \\
\text { growth }\end{array}$ & $\begin{array}{l}\text { Suppresses NF- } \kappa \mathrm{B}, \mathrm{JNK} \text {, and MAPK/ERK signaling pathways [48]; downregulates } \\
\text { full-length AR expression and activity and its constitutively active splice variants [6] }\end{array}$ \\
\hline & Antimetastasis & Downregulates MMP-9 [72] and MMP-2 [73] \\
\hline & Antiangiogenesis & Inhibits the proliferation HUVECs \\
\hline & $\begin{array}{l}\text { Synergy and } \\
\text { attenuation }\end{array}$ & $\begin{array}{l}\text { Synergies with cyclophosphamide, mitoxantrone, 5-FU, docetaxel, epicatechin, } \\
\text { paclitaxel or vinblastine, irinotecan, tamoxifen, or doxorubicin [74-76]. Reverses } \\
\text { MDR and inhibits P-gp [77] }\end{array}$ \\
\hline \multirow[t]{9}{*}{ Ginsenoside Rg3 } & Antiproliferation & $\begin{array}{l}\text { Induces calcium-dependent apoptosis and autophagy [78]; induces DNA } \\
\text { double-strand breaks [79]; downregulates HIF-1 } \alpha \text { expression under hypoxia } \\
\text { conditions [80]; downregulates PI3K/Akt [81] and three modules of MAP kinases [82]; } \\
\text { inhibits COX-2, NF- } \kappa \text { B, phosphorylation of STAT3, ERK1/2, and JNK [83] }\end{array}$ \\
\hline & $\begin{array}{l}\text { Active tumor } \\
\text { suppressors }\end{array}$ & $\begin{array}{l}\text { Induces senescence-like growth arrest by regulating Akt and p53/p21-dependent } \\
\text { signaling pathways [61] }\end{array}$ \\
\hline & $\begin{array}{l}\text { Inhibit cellular } \\
\text { metabolism }\end{array}$ & $\begin{array}{l}\text { Increases the cellular GSH/GSSG ratio, enhances the } \gamma \text {-GCS activity, and suppresses } \\
\text { ROS generation [84] }\end{array}$ \\
\hline & Antiangiogenesis & $\begin{array}{l}\text { Degrades serum IGF-1 level [85]; downregulates KDR and VEGF expressions [86]; } \\
\text { decreases intratumoral microvessel density [87]; inhibits VEGF dependent p38/ERK } \\
\text { signaling in vitro and inhibits the mobilization of endothelial progenitor cells from the } \\
\text { bone marrow microenvironment to the peripheral circulation [88] }\end{array}$ \\
\hline & $\begin{array}{l}\text { Inhibit tumor } \\
\text { growth }\end{array}$ & $\begin{array}{l}\text { Downregulates Wnt/ } \beta \text {-catenin signaling [54]; decreases HDAC3 and increases } \\
\text { acetylation of p53 [63]; decreases FUT4/LeY expression and inhibits the activation of } \\
\text { EGFR/MAPK pathway [89] }\end{array}$ \\
\hline & Antimetastasis & $\begin{array}{l}\text { Suppresses invasion and MMP-9 expression level [90]; inhibits micro-lymphatic } \\
\text { metastasis of colorectal neoplasms [91]; blocks hypoxia-induced EMT, activates the } \\
\text { ubiquitin-proteasome pathway to promote HIF-1 } \alpha \text { degradation, upregulates } \\
\text { E-cadherin via transcriptional suppression of Snail, and downregulates vimentin } \\
\text { under hypoxic conditions [92] }\end{array}$ \\
\hline & $\begin{array}{l}\text { Synergy and } \\
\text { attenuation }\end{array}$ & $\begin{array}{l}\text { Reverses P-gp-mediated MDR [93]; increases radiosensitivity [94]; synergies with } \\
\text { 5-FU, } \mathrm{As}_{2} \mathrm{O}_{3} \text { (arsenic trioxide), capecitabine, cisplatin, CTX, docetaxel, doxorubicin, } \\
\text { gemcitabine, gemcitabine plus cisplatin, mitomycin C and tegafur, paclitaxel, } \\
\text { ribonuclease inhibitor, suramin, tamoxifen, TRAIL, verapamil, and } \\
\text { vinorelbine+cisplatin [95-100] }\end{array}$ \\
\hline & Immunomodulation & $\begin{array}{l}\text { Improves cellular immunity and stimulates ConA-induced lymphocyte proliferation } \\
\text { and augmentation of Th1-type cytokines IL- } 2 \text { and IFN- } \gamma \text { levels in mice [101]; improves } \\
\text { the immune function [102] }\end{array}$ \\
\hline & $\begin{array}{l}\text { Prevent } \\
\text { tumorigenesis }\end{array}$ & $\begin{array}{l}\text { Reduces tumor incidence in N:GP(S) newborn mice injected with benzo(a)pyrene } \\
\text { [103]; downregulates NF- } \kappa \mathrm{B} \text { and AP-1 [104] }\end{array}$ \\
\hline \multirow[t]{5}{*}{ Ginsenoside Rh2 } & Antiproliferation & $\begin{array}{l}\mathrm{G}_{1} \text { phase arrest [105]; induces cell differentiation and reduces telomerase activity [106]; } \\
\text { induces } \mathrm{Ca}^{2+} \text {-dependent mitochondrial apoptosis pathway [107]; induces autophagy } \\
\text { [78]; activates NF- } \kappa \mathrm{B} \text { signaling pathway and upregulates TNF- } \alpha \text { [108]; reduces } \\
\text { Akt/mTOR signaling [109] }\end{array}$ \\
\hline & $\begin{array}{l}\text { Active tumor } \\
\text { suppressors }\end{array}$ & $\begin{array}{l}\text { Increases the expression level of DR4 death receptor [65]; upregulates miRNA-128 } \\
\text { expression [110]; activates p53 [64] }\end{array}$ \\
\hline & $\begin{array}{l}\text { Inhibit cellular } \\
\text { metabolism }\end{array}$ & $\begin{array}{l}\text { Induces AMPK and p38 MAPK activation. AMPK determines apoptotic sensitivity of } \\
\text { cancer cells to Rh2 [111] }\end{array}$ \\
\hline & $\begin{array}{l}\text { Inhibit tumor } \\
\text { growth }\end{array}$ & $\begin{array}{l}\text { Inhibits EGFR signaling through PI3K/Akt/mTOR signaling pathways [112] and } \\
\text { upregulation of miR-491 [113]; augment of TGF- } \beta \text { receptor signaling [114] }\end{array}$ \\
\hline & Antiangiogenesis & Inhibits angiogenesis and lymphangiogenesis and downregulates JAM expression [115] \\
\hline
\end{tabular}


TABle 1: Continued.

\begin{tabular}{|c|c|c|}
\hline \multirow[t]{3}{*}{ Compounds } & Activities & Mechanisms \\
\hline & $\begin{array}{l}\text { Synergy and } \\
\text { attenuation }\end{array}$ & $\begin{array}{l}\text { Synergies with cisplatin, betulinic acid, CTX, daunomycin, vinblastine, docetaxel, } \\
\text { paclitaxel, and mitoxantrone }[116,117] \text {; reverses P-gp-mediated MDR [118] }\end{array}$ \\
\hline & $\begin{array}{l}\text { Prevent } \\
\text { tumorigenesis }\end{array}$ & $\begin{array}{l}\text { Decreases the tumor incidence in N:GP(S) newborn mice injected with } \\
\text { benzo(a)pyrene model }[103,119]\end{array}$ \\
\hline \multirow[t]{9}{*}{ CK/IH-901/M1 } & Antiproliferation & $\begin{array}{l}\mathrm{G}_{1} \text { phase arrest [120]. Inhibits telomerase activity and downregulates the human TERT } \\
\text { gene [121]; induces mitochondria-dependent apoptotic pathway [122]; inhibits FGFR3 } \\
\text { expression and signaling [52]; induces autophagy [123] }\end{array}$ \\
\hline & $\begin{array}{l}\text { Active tumor } \\
\text { suppressors }\end{array}$ & $\begin{array}{l}\text { Inhibits DNA methyltransferase } 1 \text { and reactivates epigenetically silenced genes. } \mathrm{IC}_{50} \text { : } \\
20 \pm 1.0 \mu \mathrm{g} / \mathrm{mL} \text { [124]; upregulates cytochrome C, p53, and Bax expression [125] }\end{array}$ \\
\hline & $\begin{array}{l}\text { Inhibit cellular } \\
\text { metabolism }\end{array}$ & $\begin{array}{l}\text { CAMK-IV/AMPK pathways [126]; inhibits histone deacetylase activity [127]; } \\
\text { modulates AMPK-COX-2 signaling [40] }\end{array}$ \\
\hline & Anti-inflammation & $\begin{array}{l}\text { Inhibits colonic inflammation and tumorigenesis promoted by Western diet. Inhibits } \\
\text { tumor xenograft growth. Reduces EGFR and ErbB2 activation and Cox- } 2 \text { expression } \\
\text { [128] }\end{array}$ \\
\hline & $\begin{array}{l}\text { Inhibit tumor } \\
\text { growth }\end{array}$ & $\begin{array}{l}\text { Bid-mediated mitochondrial pathway [42]; increases } \mathrm{Ca}^{2+} \text { influx, mainly through } \\
\text { TRPC channels and by targeting AMPK [129] }\end{array}$ \\
\hline & Antimetastasis & $\begin{array}{l}\text { Inhibits adhesion, invasion, and spontaneous metastatic growth. Inhibition of AP-1 } \\
\text { and MAPK pathways [130]; suppresses the activation of the NF- } \kappa \text { B pathway and } \\
\text { inhibition of MMP-2/MMP-9 expression [131] }\end{array}$ \\
\hline & Antiangiogenesis & $\begin{array}{l}\text { Regulates MMP expression, as well as the activity of sphingosine kinase-1 and its } \\
\text { related sphingolipid metabolites [132]; blockades of type IV collagenase secretion [133] }\end{array}$ \\
\hline & $\begin{array}{l}\text { Synergy and } \\
\text { attenuation }\end{array}$ & $\begin{array}{l}\text { Synergies with cisplatin, CTX [134]; increases radiosensitivity [135]; decreases the } \\
\text { toxicity of irinotecan [136] }\end{array}$ \\
\hline & $\begin{array}{l}\text { Prevent } \\
\text { tumorigenesis }\end{array}$ & $\begin{array}{l}\text { Prevents tumorigenesis of aberrant crypts in C57BL: } 6 \text { mice colonized with } \\
\text { ginseng-hydrolyzing bacteria }\end{array}$ \\
\hline \multirow[t]{4}{*}{ Ginsenoside Rb1 } & Antiproliferation & Increases the expression levels of caspase-3 and caspase-8 [137] \\
\hline & Antiangiogenesis & $\begin{array}{l}\text { Inhibits the HGF/SF-induced chemoinvasion. Inhibits tyrosine kinase [10]; regulates } \\
\text { pigment epithelium-derived factor through the estrogen } \beta \text { receptor [138] }\end{array}$ \\
\hline & Attenuation & Reduces CTX-induced DNA damage and apoptosis effects [139] \\
\hline & Chemoprevention & Induces cytochrome P450 1A1 expression. Aryl hydrocarbon receptor [140] \\
\hline \multirow[t]{3}{*}{ Ginsenoside Rb2 } & Antiproliferation & Increases the expression levels of caspase-3 and caspase- $8[137]$ \\
\hline & Antimetastasis & Inhibits the adhesion and invasion and suppression of MMP-2 [141] \\
\hline & $\begin{array}{l}\text { Prevent } \\
\text { tumorigenesis }\end{array}$ & $\begin{array}{l}\text { Prevents the downregulation of gap junctional intercellular communication by TPA } \\
\text { and hydrogen peroxide [142] }\end{array}$ \\
\hline \multirow[t]{2}{*}{ Ginsenoside Rb3 } & Antiproliferation & $\begin{array}{l}\text { Inhibits DNA transferring and duplication [143]; inhibits RNF- } \alpha \text {-induced NF- } \kappa \text { B } \\
\text { activity and inhibits COX-2 and iNOS mRNA levels [144] }\end{array}$ \\
\hline & $\begin{array}{l}\text { Synergy and } \\
\text { attenuation }\end{array}$ & Increases cisplatin's antiproliferative activity in MCF-7 cells [145] \\
\hline \multirow{2}{*}{ Ginsenoside Rc } & Antiproliferation & Antiproliferation of HCT-116 and HT-29 cells [146] \\
\hline & $\begin{array}{l}\text { Synergy and } \\
\text { attenuation }\end{array}$ & $\begin{array}{l}\text { Reverses MDR, reduces the activity of the efflux pump, enhances T cell proliferation, } \\
\text { and increases the NK cell activity [147] }\end{array}$ \\
\hline \multirow[t]{3}{*}{ Ginsenoside Rd } & Antiproliferation & $\begin{array}{l}\text { Inhibits the chymotrypsin-like activity of } 26 \mathrm{~S} \text { proteasome [148]; induces apoptosis and } \\
\text { reduces oxidative stress and associates with DNA replication and repair, protein } \\
\text { synthesis and degradation, mutagenesis, and metastasis [149] }\end{array}$ \\
\hline & Antimetastasis & Blocks MMP activation and MAPK signaling pathways [55] \\
\hline & $\begin{array}{l}\text { Synergy and } \\
\text { attenuation }\end{array}$ & $\begin{array}{l}\text { Reverses MDR, reduces the activity of the efflux pump, enhances T cell proliferation, } \\
\text { and increases the NK cell activity [147] }\end{array}$ \\
\hline Ginsenoside Rk1 & Antiproliferation & $\begin{array}{l}\text { Induces apoptosis, upregulation of Fas, FasL, and Bax, and downregulation of } \\
\text { procaspase- } 8 \text { and procaspase- } 3 \text {, mutant p53, and Bcl-2 [59] }\end{array}$ \\
\hline Ginsenoside Rs3 & Antiproliferation & $\begin{array}{l}\mathrm{G}_{1} / \mathrm{S} \text { phase arrest. Elevates protein levels of } \mathrm{p} 53 \text { and } \mathrm{p} 21^{\mathrm{WAF} 1} \text { and downregulates the } \\
\text { activities of the cyclin-dependent kinases [60] }\end{array}$ \\
\hline
\end{tabular}


TABle 1: Continued.

\begin{tabular}{lll}
\hline Compounds & Activities & Mechanisms \\
\hline Ginsenoside F2 & Antiproliferation & $\begin{array}{l}\text { Induces apoptosis accompanied by protective autophagy. Activates intrinsic apoptotic } \\
\text { pathway and mitochondrial dysfunction [150] }\end{array}$ \\
& $\begin{array}{l}\text { Inhibit tumor } \\
\text { growth }\end{array}$ & $\begin{array}{l}\mathrm{IC}_{50}: 49.9 \pm 4.2 \mu \mathrm{M} \text {. Accumulation of ROS and activating the ASK-1/JNK signaling } \\
\text { pathway [19] }\end{array}$ \\
& Antimetastasis & $\mathrm{IC}_{50}: 50 \mu \mathrm{g} / \mathrm{mL}$. Activation of caspase-3 and caspase-8 and inhibition of MMP-9 [151] \\
\hline $\begin{array}{l}\text { Ginsenosides Mb, Mc, } \\
\text { and Mx }\end{array}$ & Antiproliferation & $\begin{array}{l}\text { Antiproliferation of HCT-116 and HT-29 cells [146], as well as HL-60, HGC-27, } \\
\text { Colon205, and Dul45 cells [152] }\end{array}$ \\
\hline
\end{tabular}

TABLE 2: Summary of the anticancer activities of PPT and PTS.

\begin{tabular}{|c|c|c|}
\hline Effects & Activities & Mechanisms \\
\hline $\begin{array}{l}\text { Ginsenosides F1 and } \\
\text { F5 }\end{array}$ & Antiproliferation & $\begin{array}{l}\text { Induces chromatin condensation and increases sub- } \mathrm{G}_{1} \text { hypodiploid cells. } \\
\mathrm{IC}_{50}: 23.2 \mu \mathrm{M} \text { and } 62.4 \mu \mathrm{M}[153]\end{array}$ \\
\hline \multirow[t]{2}{*}{ Ginsenoside $\operatorname{Re}$} & Antiproliferation & $\begin{array}{l}\text { Increases GSH/GSSG ratio, enhances the } \gamma \text {-GCS activity, and suppresses } \\
\text { ROS generation [84]; inhibits the transferring and duplication of DNA } \\
{[143]}\end{array}$ \\
\hline & $\begin{array}{l}\text { Synergy and } \\
\text { attenuation }\end{array}$ & Synergies with cisplatin. Increases cisplatin's antiproliferative activity [145] \\
\hline Ginsenoside Rf & Antiproliferation & $\begin{array}{l}\mathrm{G}_{2} / \mathrm{M} \text { phase arrest. } \mathrm{IC}_{50}: 11.36 \mu \mathrm{M} \text {. Upregulates Bax and downregulates } \\
\mathrm{Bcl}-2 \text {, CDK1, and cyclin } \mathrm{B} 1 \text {, activates caspase- } 3 \text { and caspase- } 9 \text {, and releases } \\
\text { cytochrome } \mathrm{C}[154]\end{array}$ \\
\hline \multirow[t]{6}{*}{ Ginsenoside Rg1 } & Antiproliferation & $\begin{array}{l}\text { Inhibits ubiquitin activating enzyme }\left(\mathrm{E}_{1}\right) \text { activity }[155] ; \mathrm{S} \text { phase arrest and } \\
\text { induces cell senescence [156]; increases the expression levels of caspase-3 } \\
\text { and caspase-8; induces apoptosis [137]; inhibits EpoR-mediated } \\
\text { JAK2/STAT5 signal pathway [157] }\end{array}$ \\
\hline & Immunomodulation & $\begin{array}{l}\text { Activates tumor killer cells and enhances the production of NO from } \\
\text { IFN- } \gamma \text { activated-macrophages [158] }\end{array}$ \\
\hline & Inhibit tumor growth & $\begin{array}{l}\text { Inhibits colon cancer growth. Downregulates the expression of cyclin D1, } \\
\text { PCNA, and VEGF [159] }\end{array}$ \\
\hline & Antimetastasis & $\begin{array}{l}\text { Suppresses TPA-induced tumor cell invasion and migration by inhibition } \\
\text { of NF- } \kappa \text { B-dependent MMP-9 expression [160]; inhibits transforming } \\
\text { growth factor- } \beta \text {-induced epithelial-to-mesenchymal transition [161] }\end{array}$ \\
\hline & $\begin{array}{l}\text { Synergy and } \\
\text { attenuation }\end{array}$ & $\begin{array}{l}\text { Synergist with IL-2. Activates lymphokine activated killer cells as a } \\
\text { synergistic of IL-2 [162] }\end{array}$ \\
\hline & Chemoprevention & $\begin{array}{l}\text { Induces cytochrome P450 1A1 expression. Aryl hydrocarbon receptor } \\
\text { [140] }\end{array}$ \\
\hline Ginsenoside Rg2 & Antiproliferation & $\mathrm{IC}_{50}: 9.0 \mu \mathrm{M}[153]$ \\
\hline \multirow[t]{2}{*}{ Ginsenoside Rh1 } & Antiproliferation & $\begin{array}{l}\text { Induces differentiation. Stimulates the nuclear translocation of } \\
\text { glucocorticoid receptor [163]; induces apoptosis [30] }\end{array}$ \\
\hline & Antimetastasis & $\begin{array}{l}\text { Inhibits the invasion and migration. Suppresses MMP-1 expression } \\
\text { through inhibition of AP-1 and MAPK signaling pathway [164]; inhibits } \\
\text { MMPs gene expression by suppressing MAPKs, PI3K/Akt, and } \\
\text { downstream NF- } \kappa \text { B and AP-1 [165] }\end{array}$ \\
\hline Notoginsenoside R1 & Antiproliferation & $\begin{array}{l}\text { Induces differentiation; affects synthesis of DNA and RNA [166]; } \\
\text { upregulates p53 gene and downregulates Bcl-2 gene [167] }\end{array}$ \\
\hline \multirow[t]{4}{*}{$\begin{array}{l}\text { Protopanaxatriol } \\
\text { (PPT) }\end{array}$} & Antiproliferation & $\begin{array}{l}\text { Increases sub- } \mathrm{G}_{1} \text { cells [168]; induces apoptosis. Activation of p53 and p21 } \\
\text { and downregulation of CDK2, cyclin E and cyclin D1, and PCNA [58] }\end{array}$ \\
\hline & Antiangiogenesis & $\begin{array}{l}\text { Inhibits the proliferative activity of HUVECs in a dose-dependent } \\
\text { manner. } \mathrm{EC}_{50}: 6.64 \mu \mathrm{g} / \mathrm{mL}[67]\end{array}$ \\
\hline & Antimetastasis & $\begin{array}{l}\text { Enhances natural-killer cytotoxicity by esterified protopanaxatriol [169]; } \\
\text { inhibits invasion and downregulation of MMP-9 [72] }\end{array}$ \\
\hline & $\begin{array}{l}\text { Synergy and } \\
\text { attenuation }\end{array}$ & $\begin{array}{l}\text { Reverses daunomycin and vinblastine resistance [170]; synergies with } \\
\text { mitoxantrone; inhibits BCRP-associated vanadate sensitive ATPase } \\
\text { activity [21] }\end{array}$ \\
\hline
\end{tabular}


of cellular adhesive molecules, matrix metalloproteinases (MMPs), and collagenases are involved in the anti-invasion effect of ginsenosides.

The results obtained by Li et al. [73] indicated that PPD significantly inhibited the invasiveness of HT1080 cells in vitro, and this action is primarily due to downregulating the expression of MMP-2. Cathcart et al. found that ginsenoside Rd dose- and time-dependently inhibited the migration and invasion of human hepatocellular carcinoma HepG2, Hep3B, SNU-398, and SNU-878 cells via reducing the expression of MMP-1, MMP-2, and MMP-7 [177] and inducing focal adhesion formation and modulating vinculin localization and expression [55].

Other reports indicated that both Rg1 and Rg3 suppress liver cancer cell HepG2 or lung cancer cell A549 migration and invasion in vitro by inhibiting the transforming growth factor- (TGF-) $\beta 1$-induced EMT $[161,178]$. The anti-invasion effects of $\mathrm{Rg} 3$ and $\mathrm{Rh} 2$ were proved related with the expression of MMP-13 both in B16F10 mouse melanoma cancer cells and in glioblastoma multiforme cells $[179,180]$. 20(S)-Rg3 also effectively inhibits EMT in nude mouse xenograft models of ovarian cancer by blocking hypoxia-induced epithelialmesenchymal transition [92] and limited metastasis and promoted survival by downregulating VEGF overexpression in HCC tumor [181].

3.4. Regulating of Tumor-Related Immune Suppression. The evidences support the effect of ginsenosides on overcoming tumor to evade the immune system. Wang et al. [182] reported that $\mathrm{CK}$ could inhibit tumor growth by decreasing the expressions of immunosuppression-related gene and suppressing the production of proinflammatory cytokines. Hao et al. found that total ginsenosides from Asian ginseng can promote the growth inhibition and apoptosis of human T lymphocyte Jurkat cells induced by PG human lung carcinoma cells, which may be related to the upregulation of cytokine TGF- $\beta 1$ secretion in PG cells [183]. Zhou et al. [184] have compared the anticancer activity of CK plus cyclophosphamide (CTX) with that of CTX alone. The result exhibited that the combination effect was significantly superior and synergistic, which might due to immunoregulation activity of CK by improving the WBC, interleukin- (IL-) 2, and interferon- (IFN-) $\gamma$ degraded of CTX. Further studies implied that OCK did not directly affect tumor growth in vitro, whereas it promoted tumor cell lysis by lymphocytes, particularly nonadherent splenocytes [185].

Dendritic cell (DC) plays a pivotal role in the initiation of $\mathrm{T}$ cell-mediated immune responses through influencing $\mathrm{T}$ cell differentiation towards the Th1, Th2, or Th17 type and regulating factors related to the direction of the $\mathrm{T}$ cell polarization [186]. PPT exerts anticancer bioactivity mainly through its ability to improve immunity on DCbased vaccines [187], and the activity of PPT is stronger than its original ginsenosides form, PTS. Stimulation with $20 \mu \mathrm{M}$ of PPT increased expression of CD80, CD83, and CD86 and decreased endocytic activity in DCs [188]. As the most important anticancer compound in ginseng, Rg3 also presented inhibition of tumor growth and immunomodulation activities in H22-tumor bearing mice attributed to the improvement of cellular immunity. It could stimulate ConAinduced lymphocyte proliferation and augmentation of Th1type cytokines IL-2 and INF- $\gamma$ levels in mice [101].

In addition to the above, ginsenosides also improve the immune destruction of organism. Jang et al. [189] indicated that methanol extract of cultured wild ginseng cambial meristematic cells (CMCs) is effective for potentiation of NK cell and anticancer activity. PPT-primed mature DCs displayed enhanced $\mathrm{T}$ cells stimulatory capacity in an allogeneic mixed lymphocyte reaction. Mature DCs differentiated with PPT induced the differentiation of naive $\mathrm{T}$ cells towards a Th1 response. The production of IFN- $\gamma$ and ${ }^{51} \mathrm{Cr}$ release on PPTprimed mature DCs was augmented, while small amounts of IL-4 depending on IL-12 secretion were investigated [188].

3.5. Deregulating Cellular Anabolism and Metabolism. More and more evidence indicated that the anticancer effect of ginsenosides is also related with its abilities on regulating abnormal tumor anabolism, metabolism, and glycolysis. Li et al. [190] showed that 20(S)-Rg3 could inhibit Warburg effect through STAT3/HK2 pathways, and 20(S)Rg3 decreased metabolic enzymes in glycolysis including PKM2, HK2, GLUT1, and LDH, but the mechanism still needed further study. Aglycone of Rh4 inhibits melanin synthesis in B16 melanoma cells via the protein kinase A pathway [191]. Investigations indicated that Rh4 significantly reduced the cyclic AMP (cAMP) level and downregulated microphthalmia-associated transcription factor and tyrosinase in B16 melanoma cells. Otherwise, Rg1 has been shown to bind to the glucocorticoid receptor (GR), leading to the downregulation of GR expression and the induction of GRmediated transcription synergistically with cAMP in FTO2B rat hepatoma cells [192].

As a kind of aldose reductase inhibitor, Rh2 induced AMPK and p38 MAPK activation and thus determined the apoptotic sensitivity of cancer cells [111]. Rg3 and its metabolite CK also impact on the cancer-related metabolism pathways like AMPK. Yuan et al. found that Rg3-induced apoptosis in HT-29 colon cancer cells is associated with AMPK signaling pathway [193]. CK-mediated cell death of HT-29 colon cancer cells is regulated by calcium/calmodulindependent protein kinase- (CAMK-) IV/AMPK pathways [126] and CK induced apoptosis by modulating AMPK-COX2 signaling in MCF-7 human breast cancer cells [40].

3.6. Inhibiting Tumor-Prompting Inflammation. Tumor promotion often accompanies an elevated ornithine decarboxylase (ODC) activity, acute inflammation, and induction of COX-2 activity, and the eukaryotic transcription factor NF- $\kappa \mathrm{B}$ has been involved in intracellular signaling pathways associated with inflammation and carcinogenesis [194]. CK has been reported to possess anti-inflammatory effects by inhibiting 12-O-tetradecanoylphorbol-13-acetate(TPA-) induced COX-2 expression. Lee et al. [195] showed that topical application of CK onto shaven backs of female ICR mice led to the inhibition of TPA-induced expression of COX-2 and production of $\mathrm{PGE}_{2}$. CK pretreatment inhibited TPA-induced epidermal NF- $\kappa$ B DNA binding in mouse skin, which appeared to be mediated by blocking phosphorylation 
and subsequent degradation of $\mathrm{I} \kappa \mathrm{B} \alpha$. The regulatory effect on COX-2 and NF- $\kappa$ B has also been found in Rg3-pretreated mouse skin stimulated by TPA [104].

3.7. Depressing Carcinogenesis. Eliminating and reducing risk factors of carcinogenesis are considered a critical step to tumor prevention and control. Korean investigators carried out extensive long-term anticarcinogenicity experiments with 2000 newborn mice stimulated by several chemical carcinogens and suggested that traditional Chinese medicine ginseng holds a potential anticancer effect [196]. There was a $22 \%$ decrease $(p<0.05)$ in the incidence of urethane induced lung adenoma by the use of red ginseng extract. Yun and colleagues indicated that red ginseng extract showed inhibition of lung tumor incidence, while fresh ginseng did not [196]. Another research from Yun's group also demonstrated that the anticarcinogenicity of ginseng was more prominent in aged or heat treated extracts of ginseng and red ginseng made by steaming. Moreover, ginsenosides Rg3, Rg5, and Rh2 were found to be active anticarcinogenic compounds [103].

The report by Keum and colleagues suggested that Rg3 also inhibits the tumor promotion. Pretreatment of dorsal skins of female ICR mice with Rg3 significantly inhibited TPA-induced ornithine decarboxylase activity and 7,12dimethylbenz[a]anthracene-initiated papilloma formation. Rg3 pretreatment also abrogated the expression of COX2 in TPA-stimulated mouse skin possibly through downregulation of NF- $\kappa \mathrm{B}$ and AP-1 transcription factors [104]. Furthermore, $\mathrm{Rb} 2$ prevents human cancers by downregulation of gap junctional intercellular communication by TPA and hydrogen peroxide in WB-F344 rat liver epithelial cells [142]. CK could prevent tumorigenesis of aberrant crypts in C57BL:6 mice colonized with ginseng-hydrolyzing bacteria [197].

Phase 2 detoxification enzymes protect against carcinogenesis and oxidative stress. Lee et al. [198] illustrated that PPD induced the activity of phase 2 detoxification enzymes. Ginseng extracts and components (such as PPD and PPT) were assayed for inducer activity of NQO1 (quinone reductase), a phase 2 enzyme, in Hepalclc7 cells. Wang et al. [140] suggested that the chemopreventive effect of Panax ginseng may be also due, in part, to ginsenosides Rgl and Rbl's ability to compete with aryl hydrocarbons for both the aryl hydrocarbon receptor and CYP1A1 in HepG2 cell.

3.8. Synergy with Chemotherapy. It is suggested that the combination of ginsenoside or notoginsenoside with chemotherapy drugs acts synergistically to produce therapeutic effects greater than those that can be achieved with single use. With the aim of increasing the activities and decreasing the side effects, the adjuvant potentials of saponins had been screened. Combining $25-\mathrm{OCH}_{3}$-PPD with conventional chemotherapeutic agents or radiation led to potent anticancer effects. The tumor regression was almost complete following administration of $25-\mathrm{OCH}_{3}-\mathrm{PPD}$ and taxotere/gemcitabine [35]. Researchers had also hypothesized that the potential therapeutic efficacy of PTS and PDS possibly could be enhanced when they are cotreated with various kinds of known tumor necrosis factor- (TNF-) $\alpha$ antagonists [119].
As is mentioned above, PPD could also be an adjuvant agent to achieve more effective anticancer activities. It has been assessed by calcein AM efflux assay that PPD was able to inhibit P-glycoprotein (P-gp) activity as potently as verapamil on MDR cells, while it did not affect ATPase activity of P-gp [77]. Combinations of PPD and docetaxel yield more additive or synergistic activity on established PC-3 tumors compared to animals treated with docetaxel alone [117]. Besides, PPD synergistically enhances cytotoxicity of tamoxifen and mitoxantrone in an estrogen receptor-independent fashion, probably by downregulating Akt activity [21, 51].

As shown in Table 1, PDS including Rc, Rd, Rb1, Rh2, and $\mathrm{Rb} 3$ show synergistic activity with chemotherapeutic drugs. Choi et al. [199] demonstrated that PTS isolated from ginseng also has a chemosensitizing effect on Pgp-mediated multidrug resistance (MDR) cells by increasing the intracellular accumulation of drugs through direct interaction with P-gp at the azidopine site. Kitagawa et al. [200] examined that PPT increased the accumulation of P-gp substrate daunorubicin 3.6-fold, more potent than that of CK. Collectively, ginseng types or ginsenosides administration might render an improved efficiency and an ameliorated toxicity of chemotherapy during cancer treatment.

\section{Conclusion}

Observations published in the last years suggest that ginsenoside could be an anticancer agent for various cancers, and the anticancer property of ginsenoside is associated with the induction of apoptosis or autophagy and inhibition of cell proliferation, metastasis, and angiogenesis, as well as modulating the immune system. As the major active components of ginseng types, PTS and PDS ginsenosides have shown wide anticancer properties with respective characteristics. Compared with PTS, PDS ginsenosides (e.g., Rg3) and its metabolites or derivates have stronger therapeutic potential for inhibiting the growth, angiogenesis, metastasis, inflammation, and immune evasion of cancer. On the other hand, PTS and PPT regulate abnormal tumor anabolism, metabolism, and glycolysis in cancer. PTS and its derivatives also depress carcinogenesis and improve the antitumor activity of chemotherapeutic drugs.

As a result of the multiple targets and signaling pathways of ginsenosides, we still could not get a clear understanding of the anticancer effect of ginseng types. But the current research has confirmed the anticancer effect of ginseng types in the aspects mentioned above. Although the research progress on ginseng has greatly promoted its application, how PTS and PDS target cancer-related signaling pathways remains unclear, and the further details and mechanism are still unknown. Thus, it is of importance to understand the characteristics and possible mechanisms associated with the anticancer effects of ginseng derivatives.

\section{Abbreviations}

25-OCH3-PPD: 20(S)-25-Methoxyl-dammarane$3 \beta, 12 \beta, 20$-triol 
25-OH-PPD: 20(R)-Dammarane-3 $\beta, 12 \beta, 20,25$-tetrol

Akt: $\quad$ Protein kinase B

ALL: $\quad$ Acute lymphoblastic leukemia

AMPK: $\quad$ AMP-activated protein kinase

cAMP: $\quad$ Cyclic AMP

AP-1: $\quad$ Activator protein-1

AR: $\quad$ Androgen receptor

ASK-1: $\quad$ Apoptosis signal regulating kinase-1

ATP: $\quad$ Adenosine triphosphate

Bcl-2: B-cell lymphoma-2

BCRP: Breast cancer resistance protein

CDK: Cyclin-dependent kinase

CK: $\quad$ Compound $\mathrm{K}$

COX-2: $\quad$ Cyclooxygenase-2

CTX: Cyclophosphamide

DC: Dendritic cell

EGFR: Epidermal growth factor receptor

EMT: $\quad$ Epithelial-mesenchymal transition

ERK: $\quad$ Extracellular signal-regulated kinase

bFGF: Basic fibroblast growth factor

FGFR3: $\quad$ Fibroblast growth factor receptor 3

FUT4: $\quad$ Fucosyltransferase 4

GCS: $\quad$ Glasgow Coma Scale

GR:

GSH:

GSSG:

HDAC3:

HGF/SF:

HIF-1:

HUVEC: Human umbilical vein endothelial cell

IFN:

IL:

JAK:

JAM:

JNK:

KDR:

MAPK:

MDR:

MMP:

MVD:

NADPH:

$\mathrm{NF}-\kappa \mathrm{B}$ :

NO:

NQO1:

OCK:

PARP:

PCNA:

PDS:

$\mathrm{PGE}_{2}$ :

PI3K:

PPD:

PPT:

PTEN:

PTS:

RNF- $\alpha$ :

ROS:

TERT:

TGF:
Glucocorticoid receptor

Glutathione

Oxidized glutathione

Histone deacetylase 3

Hepatocyte growth factor/scatter factor

Hypoxia inducible factor-1

Interferon

Interleukin

Janus activated kinase

Junctional adhesion molecule

c-Jun N-terminal kinase

Kinase insert domain receptor

Mitogen-activated protein kinase

Multidrug resistance

Matrix metalloproteinase

Mevalonate (diphosphate) decarboxylase

Nicotinamide adenine dinucleotide

phosphate

Nuclear factor-kappa B

Nitric oxide

NADPH quinone oxidoreductase 1

3-O-Oleoyl compound $\mathrm{K}$

Poly(ADP-ribose) polymerase

Proliferating cell nuclear antigen

20(S)-Protopanaxadiol saponin

Prostaglandin $\mathrm{E}_{2}$

Phosphatidylinositol 3-kinase

20(S)-Protopanaxadiol

20(S)-Protopanaxatriol

Phosphatase and tensin homolog

20(S)-Protopanaxatriol saponin

RING finger protein-alpha

Reactive oxygen species

Telomerase reverse transcriptase

Transforming growth factor
TPA: 12-O-Tetradecanoylphorbol-13-acetate

TRAIL: Tumor necrosis factor-related apoptosis-inducing ligand

TRPC: Transient receptor potential channel

VEGF: Vascular endothelial growth factor.

\section{Disclosure}

Xiao-Jia Chen and Xiao-Jing Zhang contributed equally to this work and should be considered co-first authors.

\section{Competing Interests}

The authors declare that they have no competing interests.

\section{Acknowledgments}

This work was supported by the funds from the National Natural Science Foundation of China (NSFC) (81473575 to Jian-Li Gao and 81503288 to Jian-Bo Wan).

\section{References}

[1] R. L. Siegel, K. D. Miller, and A. Jemal, "Cancer statistics, 2015," CA Cancer Journal for Clinicians, vol. 65, no. 1, pp. 5-29, 2015.

[2] W. Chen, R. Zheng, H. Zeng, S. Zhang, and J. He, "Annual report on status of cancer in China, 2011," Chinese Journal of Cancer Research, vol. 27, no. 1, pp. 2-12, 2015.

[3] L. S. Shen, Bencao Gangmu, Huaxia, Beijing, China, 1st edition, 2005.

[4] The State Pharmacopoeia Commission of People's Republic of China, Pharmacopoeia of the People's Republic of China, Chemical Industry Press, Beijing, China, 2000.

[5] State Administration of Traditional Chinese Medicine, ZhongHua Ben Cao JinXuan Ben, Shanghai Science and Technology, Shanghai, China, 1996.

[6] B. Cao, Y. Qi, Y. Yang et al., "20(S)-protopanaxadiol inhibition of progression and growth of castration-resistant prostate cancer," PLoS ONE, vol. 9, no. 11, article el11201, 2014.

[7] H. Dong, L.-P. Bai, V. K. W. Wong et al., "The in vitro structure-related anti-cancer activity of ginsenosides and their derivatives," Molecules, vol. 16, no. 12, pp. 10619-10630, 2011.

[8] K. S. Kang, T. Yokozawa, N. Y. Yamabe, H. Y. Kim, and J. H. Park, "ESR study on the structure and hydroxyl radical-scavenging activity relationships of ginsenosides isolated from Panax ginseng C. A. Meyer," Biological and Pharmaceutical Bulletin, vol. 30, no. 5, pp. 917-921, 2007.

[9] J.-B. Wan, S. M.-Y. Lee, J.-D. Wang et al., "Panax notoginseng reduces atherosclerotic lesions in ApoE-deficient mice and inhibits TNF- $\alpha$-induced endothelial adhesion molecule expression and monocyte adhesion," Journal of Agricultural and Food Chemistry, vol. 57, no. 15, pp. 6692-6697, 2009.

[10] S. Sengupta, S.-A. Toh, L. A. Sellers et al., "Modulating angiogenesis: the yin and the yang in ginseng," Circulation, vol. 110, no. 10, pp. 1219-1225, 2004.

[11] A. Rhule, S. Navarro, J. R. Smith, and D. M. Shepherd, "Panax notoginseng attenuates LPS-induced pro-inflammatory mediators in RAW264.7 cells," Journal of Ethnopharmacology, vol. 106, no. 1, pp. 121-128, 2006. 
[12] S. Shibata, "Chemistry and cancer preventing activities of ginseng saponins and some related triterpenoid compounds," Journal of Korean Medical Science, vol. 16, pp. S28-S37, 2001.

[13] W. Wang, G.-J. Wang, H.-T. Xie et al., "Determination of ginsenoside $\mathrm{Rd}$ in dog plasma by liquid chromatography-mass spectrometry after solid-phase extraction and its application in dog pharmacokinetics studies," Journal of Chromatography B: Analytical Technologies in the Biomedical and Life Sciences, vol. 852, no. 1-2, pp. 8-14, 2007.

[14] P. Y. K. Yue, N. K. Mak, Y. K. Cheng et al., "Pharmacogenomics and the Yin/Yang actions of ginseng: anti-tumor, angiomodulating and steroid-like activities of ginsenosides," Chinese Medicine, vol. 2, article 6, 2007.

[15] S. H. Shim, K.-H. Baek, and Y. S. Kim, "Inhibition of human 20 S proteasome by ginsenosides from Panax ginseng," Bulletin of the Korean Chemical Society, vol. 30, no. 6, pp. 1385-1387, 2009.

[16] A. G. Musende, A. Eberding, C. A. Wood et al., "A novel oral dosage formulation of the ginsenoside aglycone protopanaxadiol exhibits therapeutic activity against a hormone-insensitive model of prostate cancer," Anti-Cancer Drugs, vol. 23, no. 5, pp. 543-552, 2012.

[17] H. Hasegawa, "Proof of the mysterious efficacy of ginseng: basic and clinical trials: metabolic activation of ginsenoside: deglycosylation by intestinal bacteria and esterification with fatty acid," Journal of Pharmacological Sciences, vol. 95, no. 2, pp. 153-157, 2004.

[18] W. Li, Y. Liu, J. W. Zhang et al., "Anti-androgen-independent prostate cancer effects of ginsenoside metabolites In vitro: mechanism and possible structure-activity relationship investigation," Archives of Pharmacal Research, vol. 1, pp. 49-57, 2009.

[19] Q. Mao, P.-H. Zhang, Q. Wang, and S.-L. Li, "Ginsenoside F2 induces apoptosis in humor gastric carcinoma cells through reactive oxygen species-mitochondria pathway and modulation of ASK-1/JNK signaling cascade in vitro and in vivo," Phytomedicine, vol. 21, no. 4, pp. 515-522, 2014.

[20] J. I. Lee, Y. W. Ha, T. W. Choi et al., "Cellular uptake of ginsenosides in Korean white ginseng and red ginseng and their apoptotic activities in human breast cancer cells," Planta Medica, vol. 77, no. 2, pp. 133-140, 2011.

[21] J. Jin, S. Shahi, H. K. Kang, H. W. van Veen, and T.-P. Fan, "Metabolites of ginsenosides as novel BCRP inhibitors," Biochemical and Biophysical Research Communications, vol. 345, no. 4, pp. 1308-1314, 2006.

[22] D.-F. Toh, D. N. Patel, E. C. Y. Chan, A. Teo, S.-Y. Neo, and H.L. Koh, "Anti-proliferative effects of raw and steamed extracts of Panax notoginseng and its ginsenoside constituents on human liver cancer cells," Chinese Medicine, vol. 6, article 4, 2011.

[23] Y.-W. Lin, Y.-C. Mou, C.-C. Su, and B.-H. Chiang, "Antihepatocarcinoma activity of lactic acid bacteria fermented Panax notoginseng," Journal of Agricultural and Food Chemistry, vol. 58, no. 15, pp. 8528-8534, 2010.

[24] X. Liu, L. Qiao, D. Xie et al., "Microbial transformation of ginsenoside-Rg 1 by Absidia coerulea and the reversal activity of the metabolites towards multi-drug resistant tumor cells," Fitoterapia, vol. 82, no. 8, pp. 1313-1317, 2011.

[25] E.-A. Bae, J.-E. Shin, and D.-H. Kim, "Metabolism of ginsenoside Re by human intestinal microflora and its estrogenic effect," Biological and Pharmaceutical Bulletin, vol. 28, no. 10, pp. 19031908, 2005.

[26] M. Han, J.-G. Hou, C.-M. Dong et al., "Isolation, synthesis and structures of ginsenoside derivatives and their anti-tumor bioactivity," Molecules, vol. 15, no. 1, pp. 399-406, 2010.
[27] Z.-G. Yang, H.-X. Sun, and Y.-P. Ye, "Ginsenoside Rd from Panax notoginseng is cytotoxic towards HeLa cancer cells and induces apoptosis," Chemistry and Biodiversity, vol. 3, no. 2, pp. 187-197, 2006.

[28] G.-Y. Liu, X. Bu, H. Yan, and W. W.-G. Jia, "20S-Protopanaxadiol-induced programmed cell death in glioma cells through caspase-dependent and -independent pathways," Journal of Natural Products, vol. 70, no. 2, pp. 259-264, 2007.

[29] G.-Y. Zhu, Y.-W. Li, A. K.-W. Tse et al., "20(S)-Protopanaxadiol, a metabolite of ginsenosides, induced cell apoptosis through endoplasmic reticulum stress in human hepatocarcinoma HepG2 cells," European Journal of Pharmacology, vol. 668, no. 1-2, pp. 88-98, 2011.

[30] D. G. Popovich and D. D. Kitts, "Structure-function relationship exists for ginsenosides in reducing cell proliferation and inducing apoptosis in the human leukemia (THP-1) cell line," Archives of Biochemistry and Biophysics, vol. 406, no. 1, pp. 1-8, 2002.

[31] L. H. Sun, Q. Wang, X. M. Liu et al., "Anti-cancer effects of 20(S)-protopanoxadiol on human acute lymphoblastic leukemia cell lines Reh and RS4;11," Medical Oncology, vol. 28, no. 3, pp. 813-821, 2011.

[32] W. Wang, E. R. Rayburn, J. Hang, Y. Q. Zhao, H. Wang, and $\mathrm{R}$. W. Zhang, "Anti-lung cancer effects of novel ginsenoside 25$\mathrm{OCH}_{3}$-PPD," Lung Cancer, vol. 65, no. 3, pp. 306-311, 2009.

[33] X. Bi, Y. Zhao, W. Fang, and W. Yang, "Anticancer activity of Panax notoginseng extract 20(S)-25-OCH3-PPD: Targetting $\beta$-catenin signalling," Clinical and Experimental Pharmacology and Physiology, vol. 36, no. 11, pp. 1074-1078, 2009.

[34] Y.-L. Wu, Y. Wan, X.-J. Jin et al., " $25-\mathrm{OCH}_{3}-\mathrm{PPD}$ induces the apoptosis of activated t-HSC/Cl-6 cells via c-FLIP-mediated NF- $\kappa$ B activation," Chemico-Biological Interactions, vol. 194, no. 2-3, pp. 106-112, 2011.

[35] W. Wang, H. Wang, E. R. Rayburn, Y. Zhao, D. L. Hill, and R. Zhang, "20(S)-25-methoxyl-dammarane-3 $\beta, 12 \beta, 20$-triol, a novel natural product for prostate cancer therapy: activity in vitro and in vivo and mechanisms of action," British Journal of Cancer, vol. 98, no. 4, pp. 792-802, 2008.

[36] T. Akao, M. Kanaoka, and K. Kobashi, "Appearance of compound $\mathrm{K}$, a major metabolite of ginsenoside Rb1 by intestinal bacteria, in rat plasma after oral administration: measurement of compound K by enzyme immunoassay," Biological \& Pharmaceutical Bulletin, vol. 21, no. 3, pp. 245-249, 1998.

[37] W. Zhou, M.-Q. Feng, J.-Y. Li, and P. Zhou, "Studies on the preparation, crystal structure and bioactivity of ginsenoside compound K," Journal of Asian Natural Products Research, vol. 8, no. 6, pp. 519-527, 2006.

[38] K. Suda, K. Murakami, J. Murata, H. Hasegawa, and I. Saiki, "An intestinal bacterial metabolite (M1) of ginseng protopanaxadiol saponins inhibits tumor-induced neovascularization," Wakan Iyakugaku Zasshi, vol. 17, no. 4, pp. 144-150, 2000.

[39] H. Hasegawa, "Metabolic activation of ginsenoside against cancer: intestinal bacterial deglycosylation and hepatic fattyacid esterification," Wakan Iyakugaku Zasshi, vol. 18, no. 6, pp. 217-228, 1997.

[40] A. D. Kim, K. A. Kang, R. Zhang et al., "Ginseng saponin metabolite induces apoptosis in MCF-7 breast cancer cells through the modulation of AMP-activated protein kinase," Environmental Toxicology and Pharmacology, vol. 30, no. 2, pp. 134-140, 2010.

[41] H. W. Yim, H.-S. Jong, Y. K. Tai et al., "Cyclooxygenase-2 inhibits novel ginseng metabolite-mediated apoptosis," Cancer Research, vol. 65, no. 5, pp. 1952-1960, 2005. 
[42] C. Hu, G. Song, B. Zhang et al., "Intestinal metabolite compound $\mathrm{K}$ of panaxoside inhibits the growth of gastric carcinoma by augmenting apoptosisviaBid-mediated mitochondrial pathway," Journal of Cellular and Molecular Medicine, vol. 16, no. 1, pp. 96-106, 2012.

[43] S.-H. Cho, K.-S. Chung, J.-H. Choi, D.-H. Kim, and K.-T. Lee, "Compound $\mathrm{K}$, a metabolite of ginseng saponin, induces apoptosis via caspase-8-dependent pathway in HL-60 human leukemia cells," BMC Cancer, vol. 9, article 149, pp. 449-461, 2009.

[44] K. A. Kang, Y. W. Kim, and S. U. Kim, "G ${ }_{1}$ phase arrest of the cell cycle by a ginseng metabolite, compound K, in U937 human monocytic leukamia cells," Archives of Pharmacal Research, vol. 28, no. 6, pp. 685-690, 2005.

[45] I. Saiki, "In vivo anti-metastatic action in ginseng saponins is based on their intestinal bacterial metabolites after oral administration," Journal of Ginseng Research, vol. 31, no. 1, pp. $1-13,2007$.

[46] X. Wang and Y. Wang, "Ginsenoside Rh2 mitigates pediatric leukemia through suppression of Bcl-2 in leukemia cells," Cellular Physiology and Biochemistry, vol. 37, no. 2, pp. 641-650, 2015.

[47] S. Liu, M. Chen, P. Li et al., "Ginsenoside Rh2 inhibits cancer stem-like cells in skin squamous cell carcinoma," Cellular Physiology and Biochemistry, vol. 36, no. 2, pp. 499-508, 2015.

[48] J.-L. Gao, G.-Y. Lv, B.-C. He et al., "Ginseng saponin metabolite 20(S)-protopanaxadiol inhibits tumor growth by targeting multiple cancer signaling pathways," Oncology Reports, vol. 30, no. 1, pp. 292-298, 2013.

[49] J.-W. Hwang, Y.-M. Baek, I.-S. Jang et al., "An enzymatically fortified ginseng extract inhibits proliferation and induces apoptosis of KATO3 human gastric cancer cells via modulation of Bax, mTOR, PKB and $\mathrm{I} \kappa \mathrm{B} \alpha$," Molecular Medicine Reports, vol. 11, no. 1, pp. 670-676, 2015.

[50] Y.-L. Zhang, R. Zhang, H.-L. Xu, X.-F. Yu, S.-C. Qu, and D.-Y. Sui, "20(S)-protopanaxadiol triggers mitochondrial-mediated apoptosis in human lung adenocarcinoma A549 cells via inhibiting the PI3K/Akt signaling pathway," The American Journal of Chinese Medicine, vol. 41, no. 5, pp. 1137-1152, 2013.

[51] Y. Yu, Q. Zhou, Y. Hang, X. Bu, and W. Jia, "Antiestrogenic effect of 20S-protopanaxadiol and its synergy with tamoxifen on breast cancer cells," Cancer, vol. 109, no. 11, pp. 2374-2382, 2007.

[52] H. H. Choi, H.-S. Jong, J.-H. Park et al., "A novel ginseng saponin metabolite induces apoptosis and down-regulates fibroblast growth factor receptor 3 in myeloma cells," International Journal of Oncology, vol. 23, no. 4, pp. 1087-1093, 2003.

[53] S. Park, H.-J. Lee, S.-J. Jeong et al., "Inhibition of JAK1/STAT3 signaling mediates compound $\mathrm{K}$-induced apoptosis in human multiple myeloma U266 cells," Food and Chemical Toxicology, vol. 49, no. 6, pp. 1367-1372, 2011.

[54] B.-C. He, J.-L. Gao, X. Luo et al., "Ginsenoside Rg3 inhibits colorectal tumor growth through the down-regulation of Wnt $/ \beta$ catenin signaling," International Journal of Oncology, vol. 38, no. 2, pp. 437-445, 2011.

[55] J.-H. Yoon, Y.-J. Choi, S.-W. Cha, and S.-G. Lee, "Anti-metastatic effects of ginsenoside Rd via inactivation of MAPK signaling and induction of focal adhesion formation," Phytomedicine, vol. 19, no. 3-4, pp. 284-292, 2012.
[56] N. Riaz, L. G. Morris, W. Lee, and T. A. Chan, "Unraveling the molecular genetics of head and neck cancer through genomewide approaches," Genes and Diseases, vol. 1, no. 1, pp. 75-86, 2014.

[57] Z. Zhang, G.-J. Du, C.-Z. Wang et al., "Compound K, a ginsenoside metabolite, inhibits colon cancer growth via multiple pathways including p53-p21 interactions," International Journal of Molecular Sciences, vol. 14, no. 2, pp. 2980-2995, 2013.

[58] S. J. Hwang, J. Y. Cha, S. G. Park et al., "Diol- and triol-type ginseng saponins potentiate the apoptosis of $\mathrm{NIH}_{3} \mathrm{~T}_{3}$ cells exposed to methyl methanesulfonate," Toxicology and Applied Pharmacology, vol. 181, no. 3, pp. 192-202, 2002.

[59] J. S. Kim, E. J. Joo, J. Chun et al., "Induction of apoptosis by ginsenoside Rk1 in SK-MEL-2-human melanoma," Archives of Pharmacal Research, vol. 35, no. 4, pp. 717-722, 2012.

[60] S.-E. Kim, Y. H. Lee, J. H. Park, and S. K. Lee, "Ginsenoside-Rs3, a new diol-type ginseng saponin, selectively elevates protein levels of $\mathrm{p} 53$ and p21(WAF1) leading to induction of apoptosis in SK-HEP-1 cells," Anticancer Research, vol. 19, no. 1, pp. 487-491, 1999.

[61] S. Sin, S. Y. Kim, and S. S. Kim, "Chronic treatment with ginsenoside Rg3 induces Akt-dependent senescence in human glioma cells," International Journal of Oncology, vol. 41, no. 5, pp. 1669-1674, 2012.

[62] Y.-J. Choi, L.-J. Kang, and S.-G. Lee, "Stimulation of DDX3 expression by ginsenoside Rg3 through the Akt/p53 pathway activates the innate immune response via TBK1/IKKe/IRF3 signalling," Current Medicinal Chemistry, vol. 21, no. 8, pp.10501060, 2014.

[63] X. Shan, Y.-S. Fu, F. Aziz, X.-Q. Wang, Q. Yan, and J.-W. Liu, "Ginsenoside Rg3 inhibits melanoma cell proliferation through down-regulation of histone deacetylase 3 (HDAC3) and increase of p53 acetylation," PLoS ONE, vol. 9, no. 12, article el15401, 2014.

[64] B. Li, J. Zhao, C.-Z. Wang et al., "Ginsenoside Rh2 induces apoptosis and paraptosis-like cell death in colorectal cancer cells through activation of p53," Cancer Letters, vol. 301, no. 2, pp. 185-192, 2011.

[65] C.-C. Cheng, S.-M. Yang, C.-Y. Huang, J.-C. Chen, W.-M. Chang, and S.-L. Hsu, "Molecular mechanisms of ginsenoside Rh2-mediated G1 growth arrest and apoptosis in human lung adenocarcinoma A549 cells," Cancer Chemotherapy and Pharmacology, vol. 55, no. 6, pp. 531-540, 2005.

[66] X.-X. Guo, Y. Li, C. Sun et al., "p53-dependent Fas expression is critical for Ginsenoside Rh2 triggered caspase- 8 activation in HeLa cells," Protein and Cell, vol. 5, no. 3, pp. 224-234, 2014.

[67] Y. Usami, Y.-N. Liu, A.-S. Lin et al., "Antitumor agents. 261. 20(S)-protopanaxadiol and 20(S)-protopanaxatriol as antiangiogenic agents and total assignment of $1 \mathrm{H}$ NMR spectra," Journal of Natural Products, vol. 71, no. 3, pp. 478-481, 2008.

[68] A. Jeong, H.-J. Lee, S.-J. Jeong et al., “Compound K inhibits basic fibroblast growth factor-induced angiogenesis via regulation of p38 mitogen activated protein kinase and AKT in human umbilical vein endothelial cells," Biological \& Pharmaceutical Bulletin, vol. 33, no. 6, pp. 945-950, 2010.

[69] T. Ota, M. Maeda, and S. Odashima, "Mechanism of action of ginsenoside Rh2: uptake and metabolism of ginsenoside Rh2 by cultured B16 melanoma cells," Journal of Pharmaceutical Sciences, vol. 80, no. 12, pp. 1141-1146, 1991. 
[70] Y. H. Jin, H. Yim, J. H. Park, and S. K. Lee, "Cdk2 activity is associated with depolarization of mitochondrial membrane potential during apoptosis," Biochemical and Biophysical Research Communications, vol. 305, no. 4, pp. 974-980, 2003.

[71] C.-Z. Wang, B. Li, X.-D. Wen et al., "Paraptosis and NF- $\kappa$ B activation are associated with protopanaxadiol-induced cancer chemoprevention," BMC Complementary and Alternative Medicine, vol. 13, article 2, 2013.

[72] M.-T. Park, H.-J. Cha, J.-W. Jeong et al., "Glucocorticoid receptor-induced down-regulation of MMP-9 by ginseng components, PD and PT contributes to inhibition of the invasive capacity of HT1080 human fibrosarcoma cells," Molecules and Cells, vol. 9, no. 5, pp. 476-483, 1999.

[73] G. Li, Z. H. Wang, Y. X. Sun, K. Liu, and Z. R. Wang, "Ginsenoside 20(S)-protopanaxadiol inhibits the proliferation and invasion of human fibrosarcoma HT1080 cells," Basic and Clinical Pharmacology and Toxicology, vol. 98, no. 6, pp. 588-592, 2006.

[74] Y. Liu, G. Yang, X. Bu et al., "Cell-type-specific regulation of raftassociated Akt signaling," Cell Death and Disease, vol. 2, no. 4, article e145, 2011.

[75] G.-J. Du, C.-Z. Wang, Z.-Y. Zhang et al., "Caspase-mediated pro-apoptotic interaction of panaxadiol and irinotecan in human colorectal cancer cells," Journal of Pharmacy and Pharmacology, vol. 64, no. 5, pp. 727-734, 2012.

[76] B. Park, Y.-M. Lee, J.-S. Kim et al., "Neutral sphingomyelinase 2 modulates cytotoxic effects of protopanaxadiol on different human cancer cells," BMC Complementary and Alternative Medicine, vol. 13, article 194, 2013.

[77] Y. Zhao, L. Bu, H. Yan, and W. Jia, "20S-protopanaxadiol inhibits P-glycoprotein in multidrug resistant cancer cells," Planta Medica, vol. 75, no. 10, pp. 1124-1128, 2009.

[78] J. H. Cheong, H. Kim, M. J. Hong et al., "Stereoisomer-specific anticancer activities of ginsenoside Rg3 and Rh2 in HepG2 cells: disparity in cytotoxicity and autophagy-inducing effects due to 20(S)-epimers," Biological and Pharmaceutical Bulletin, vol. 38, no. 1, pp. 102-108, 2015.

[79] Y.-H. Zhang, H.-D. Li, B. Li, S.-D. Jiang, and L.-S. Jiang, "Ginsenoside Rg3 induces DNA damage in human osteosarcoma cells and reduces MNNG-induced DNA damage and apoptosis in normal human cells," Oncology Reports, vol. 31, no. 2, pp. 919925, 2014.

[80] B.-S. Wang, L.-S. Zhang, D.-M. Song, J.-H. Zhang, and Y.-M. Liu, "Effect of gensenoside Rg3 on apoptosis of Hep-2 and expression of HIF-lalha in human laryngeal cancer cell line under anoxic conditions," Journal of Chinese Medicinal Materials, vol. 32, no. 1, pp. 102-106, 2009.

[81] J.-H. Wang, J.-F. Nao, M. Zhang, and P. He, "20(s)-ginsenoside $\mathrm{Rg} 3$ promotes apoptosis in human ovarian cancer HO-8910 cells through PI3K/Akt and XIAP pathways," Tumor Biology, vol. 35, no. 12, pp. 11985-11994, 2014.

[82] H.-S. Kim, E.-H. Lee, S.-R. Ko, K.-J. Choi, J.-H. Park, and D.-S. Im, "Effects of ginsenosides Rg3 and Rh2 on the proliferation of prostate cancer cells," Archives of Pharmacal Research, vol. 27, no. 4, pp. 429-435, 2004.

[83] Q.-J. Chen, M.-Z. Zhang, and L.-X. Wang, "Gensenoside Rg3 inhibits hypoxia-induced VEGF expression in human cancer cells," Cellular Physiology and Biochemistry, vol. 26, no. 6, pp. 849-858, 2010.

[84] W. Y. Ng and M. S. Yang, "Effects of ginsenosides Re and Rg3 on intracellular redox state and cell proliferation in C6 glioma cells," Chinese Medicine, vol. 3, article 8, 2008.
[85] H.-B. Tang, Y.-P. Ren, J. Zhang, S.-H. Ma, F. Gao, and Y.P. Wu, "Correlation of insulin-like growth factor-1 (IGF-1) to angiogenesis of breast cancer in IGF-1-deficient mice," Chinese Journal of Cancer, vol. 26, no. 11, pp. 1215-1220, 2007.

[86] X. Wang, Y.-L. Zheng, K. Li, N. Lin, and Q.-X. Fan, "The effects of ginsenosides Rg3 on the expressions of VEGF and KDR in human lung squamous cancer cells," Journal of Chinese medicinal materials, vol. 32, no. 11, pp. 1708-1710, 2009.

[87] H. Tao, M. Yao, S. Zou, D. Zhao, and H. Qiu, "Effect of angiogenesis inhibitor $\operatorname{Rg} 3$ on the growth and metastasis of gastric cancer in SCID mice," Zhonghua Wai Ke Za Zhi, vol. 40, no. 8, pp. 606-608, 2002.

[88] J.-W. Kim, S.-Y. Jung, Y.-H. Kwon et al., “Ginsenoside Rg3 attenuates tumor angiogenesis via inhibiting bioactivities of endothelial progenitor cells," Cancer Biology and Therapy, vol. 13, no. 7, pp. 504-515, 2012.

[89] X. Shan, F. Aziz, L. L. Tian, X. Q. Wang, Q. Yan, and J. W. Liu, "Ginsenoside Rg3-induced EGFR/MAPK pathway deactivation inhibits melanoma cell proliferation by decreasing FUT4/LeY expression," International Journal of Oncology, vol. 46, no. 4, pp. 1667-1676, 2015.

[90] X. Jiang, Y. Xin, T.-M. Xu, and Y.-Q. Qu, "Effects of ginsenoside $\mathrm{Rg} 3$ on the invasion and metastasis of mouse melanoma cell line B16 as well as the expression of MMP-9," Tumor, vol. 31, no. 2, pp. 117-121, 2011.

[91] Y. Yu, G.-M. Zhang, J. Su, L.-H. Shang, and G. Chen, "Effects of ginsenoside $\mathrm{Rg} 3$ on the micro-lymphatic metastasis of colorectal neoplasms," Chinese Journal of Oncology, vol. 27, no. 12, p. 742, 2005.

[92] T. Liu, L. Zhao, Y. Zhang et al., "Ginsenoside 20(S)-Rg3 targets HIF- $1 \alpha$ to Block hypoxia-induced epithelial-mesenchymal transition in ovarian cancer cells," PLoS ONE, vol. 9, no. 9, Article ID e103887, 2014.

[93] J.-B. He, H.-Z. Liao, and Y.-Q. Zhang, "Ginsenoside Rg3 reverses multidrug resistance of lung adenocarcinoma in mice," Journal of Practical Oncology, vol. 27, no. 4, pp. 373-378, 2012.

[94] B.-S. Sun, X.-L. Liu, L.-L. Liu, S.-B. Fu, Z.-F. Wu, and S.-L. Gong, "Suppressive effects of ginsenoside Rg3 combined with X-ray irradiation on growth of melanoma cells," Journal of Jilin University Medicine Edition, vol. 32, no. 6, pp. 1016-1018, 2006.

[95] N. Nie, X.-L. Wu, H.-C. Luo, B. Liu, and Q. Liu, "Inhibitory effect of 5-fluorouracil combined with $\mathrm{Rg} 3$ on proliferation of gastric cancer cells," Journal of Shanghai Jiaotong University (Medical Science), vol. 34, no. 5, pp. 645-649, 2014.

[96] C.-K. Lee, K.-K. Park, A.-S. Chung, and W.-Y. Chung, "Ginsenoside $\operatorname{Rg} 3$ enhances the chemosensitivity of tumors to cisplatin by reducing the basal level of nuclear factor erythroid 2-related factor 2-mediated heme oxygenase-1/NAD $(\mathrm{P}) \mathrm{H}$ quinone oxidoreductase- 1 and prevents normal tissue damage by scavenging cisplatin-induced intracellular reactive oxygen species," Food and Chemical Toxicology, vol. 50, no. 7, pp. 2565-2574, 2012.

[97] S.-S. Kim, S. Seong, and S.-Y. Kim, "Synergistic effect of ginsenoside $\operatorname{Rg} 3$ with verapamil on the modulation of multidrug resistance in human acute myeloid leukemia cells," Oncology Letters, vol. 7, no. 4, pp. 1265-1269, 2014.

[98] L.-Q. Yang, B. Wang, H. Gan et al., "Enhanced oral bioavailability and anti-tumour effect of paclitaxel by 20(s)-ginsenoside $\mathrm{Rg} 3$ in vivo," Biopharmaceutics \& Drug Disposition, vol. 33, no. 8, pp. 425-436, 2012

[99] X.-H. Xu, J.-B. He, and P. Zhang, "Effects of Ginsenoside Rg3 in combination with Suramin on growth of lung cancer in mice," 
Chinese Journal of Cancer Prevention and Treatment, vol. 20, no. 2, pp. 97-101, 2013.

[100] J.-B. Che, Z.-H. Liu, H.-B. Ma et al., "Influence of $\mathrm{As}_{2} \mathrm{O}_{3}$ combined with ginsenosides $\mathrm{Rg} 3$ on inhibition of lung cancer NCI-H1299 cells and on subsistence of nude mice bearing hepatoma," Asian Pacific Journal of Tropical Medicine, vol. 7, no. 10, pp. 772-775, 2014.

[101] R. Wu, Q. Ru, L. Chen, B. Ma, and C. Li, "Stereospecificity of ginsenoside $\mathrm{Rg} 3$ in the promotion of cellular immunity in hepatoma H22-bearing mice," Journal of Food Science, vol. 79, no. 7, pp. H1430-H1435, 2014.

[102] P. Lu, W. Su, Z.-H. Miao, H.-R. Niu, and Q.-L. Hua, "Effect and mechanism of ginsenoside Rg3 on postoperative life span of patients with non-small cell lung cancer," Chinese Journal of Integrative Medicine, vol. 14, no. 1, pp. 33-36, 2008.

[103] T.-K. Yun, "Experimental and epidemiological evidence on non-organ specific cancer preventive effect of Korean ginseng and identification of active compounds," Mutation ResearchFundamental and Molecular Mechanisms of Mutagenesis, vol. 523-524, pp. 63-74, 2003.

[104] Y.-S. Keum, S.-S. Han, K.-S. Chun et al., "Inhibitory effects of the ginsenoside $\mathrm{Rg} 3$ on phorbol ester-induced cyclooxygenase-2 expression, NF- $\kappa$ B activation and tumor promotion," Mutation Research-Fundamental and Molecular Mechanisms of Mutagenesis, vol. 523-524, pp. 75-85, 2003.

[105] T. Ota, M. Maeda, S. Odashima, J. Ninomiya-Tsuji, and M. Tatsuka, "G1 phase-specific suppression of the Cdk2 activity by ginsenoside Rh2 in cultured murine cells," Life Sciences, vol. 60, no. 2, pp. PL39-PL44, 1996.

[106] X.-L. Zeng and Z.-G. Tu, "Effects of ginsenoside Rh2 on signal transduction in hepatocarcinoma SMMC-7721 cells," Chinese Journal of Hepatology, vol. 12, no. 9, pp. 565-566, 2004.

[107] W. Ge and S.-J. Yang, "Molecular mechanism of G-Rh2-induced apoptosis in gastric carcinoma cells," World Chinese Journal of Digestology, vol. 15, no. 28, pp. 2972-2976, 2007.

[108] H. Yu, J. Hou, X. Qi, Y. Shi, S. Li, and C. Zhang, "20 (S)ginsenoside-Rh2 induces apoptosis in human lung adenocarcinoma A549 cells by activating NF- $\kappa$ B signaling pathway," Journal of Pure and Applied Microbiology, vol. 7, no. 1, pp. 287294, 2013.

[109] Z.-M. You, L. Zhao, J. Xia et al., "Down-regulation of phosphoglucose isomerase/autocrine motility factor enhances gensenoside Rh2 pharmacological action on leukemia KG1 $\alpha$ cells," Asian Pacific Journal of Cancer Prevention, vol. 15, no. 3, pp. 1099-1104, 2014.

[110] N. Wu, G.-C. Wu, R. Hu, M. Li, and H. Feng, "Ginsenoside Rh2 inhibits glioma cell proliferation by targeting microRNA-128," Acta Pharmacologica Sinica, vol. 32, no. 3, pp. 345-353, 2011.

[111] M.-J. Kim, H. Yun, D.-H. Kim et al., "Amp-activated protein kinase determines apoptotic sensitivity of cancer cells to ginsenoside-Rh2," Journal of Ginseng Research, vol. 38, no. 1, pp. 16-21, 2014.

[112] S. Li, Y. Gao, W. Ma et al., "EGFR signaling-dependent inhibition of glioblastoma growth by ginsenoside Rh2," Tumor Biology, vol. 35, no. 6, pp. 5593-5598, 2014.

[113] W. Chen and Y. Qiu, "Ginsenoside Rh2 targets EGFR by upregulation of miR-491 to enhance anti-tumor activity in hepatitis B virus-related hepatocellular carcinoma," Cell Biochemistry and Biophysics, vol. 72, no. 2, pp. 325-331, 2015.

[114] Q. Zhang, B. Hong, S. Wu, and T. Niu, "Inhibition of prostatic cancer growth by ginsenoside Rh2," Tumor Biology, vol. 36, no. 4, pp. 2377-2381, 2015.
[115] H.-K. Yang, Y.-H. Lü, H.-D. Liu et al., "Effect of ginsenoside Rh2 on VEGF-C and lymphangiogenesis in the mouse-transplanted tumor," Acta Anatomica Sinica, vol. 40, no. 2, pp. 265-268, 2009.

[116] Q. Li, X.-Y. Wang, Y. Li, and Y.-H. Jin, "Mechanism of ginsenoside Rh2 in enhancing sensitivity of human liver cancer HepG2 cells to betulinic acid," Chinese Journal of Biologicals, vol. 24, no. 5, pp. 531-542, 2011.

[117] A. G. Musende, A. Eberding, W. Jia, E. Ramsay, M. B. Bally, and E. T. Guns, "Rh2 or its aglycone aPPD in combination with docetaxel for treatment of prostate cancer," Prostate, vol. 70, no. 13, pp. 1437-1447, 2010.

[118] H. Zhang, H.-Q. Wang, H.-L. Zhang, D. Kong, and X.-Z. Wu, "Ginsenoside Rh2 reverses P-glycoprotein-mediated multidrug resistance of MCF-7/ADM cells," Tumor, vol. 27, no. 5, pp. 365369, 2007.

[119] J. Y. Cho, E. S. Yoo, K. U. Baik, M. H. Park, and B. H. Han, "In vitro inhibitory effect of protopanaxadiol ginsenosides on tumor necrosis factor (TNF)- $\alpha$ production and its modulation by known TNF- $\alpha$ antagonists," Planta Medica, vol. 67, no. 3, pp. 213-218, 2001.

[120] Y. Chen, Y. Xu, Y. Zhu, and X. Li, "Anti-cancer effects of ginsenoside compound $\mathrm{k}$ on pediatric acute myeloid leukemia cells," Cancer Cell International, vol. 13, article 24, 2013.

[121] K. A. Kang, K. H. Lee, S. Chae et al., "Inhibition of telomerase activity in U937 human monocytic leukemia cells by Compound K, a ginseng saponin metabolite," Biotechnology and Bioprocess Engineering, vol. 11, no. 1, pp. 7-12, 2006.

[122] I. K. Lee, K. A. Kang, C. M. Lim et al., "Compound K, a metabolite of ginseng saponin, induces mitochondria-dependent and caspase-dependent apoptosis via the generation of reactive oxygen species in human colon cancer cells," International Journal of Molecular Sciences, vol. 11, no. 12, pp. 4916-4931, 2010.

[123] A. D. Kim, K. A. Kang, H. S. Kim et al., "A ginseng metabolite, compound $\mathrm{K}$, induces autophagy and apoptosis via generation of reactive oxygen species and activation of JNK in human colon cancer cells," Cell Death and Disease, vol. 4, no. 8, article e750, 2013.

[124] K. A. Kang, H. S. Kim, D. H. Kim, and J. W. Hyun, "The role of a ginseng saponin metabolite as a DNA methyltransferase inhibitor in colorectal cancer cells," International Journal of Oncology, vol. 43, no. 1, pp. 228-236, 2013.

[125] Y.-L. Ming, G. Song, L.-H. Chen et al., "Anti-proliferation and apoptosis induced by a novel intestinal metabolite of ginseng saponin in human hepatocellular carcinoma cells," Cell Biology International, vol. 31, no. 10, pp. 1265-1273, 2007.

[126] D. Y. Kim, M. W. Park, H. D. Yuan, H. J. Lee, S. H. Kim, and S. H. Chung, "Compound $\mathrm{K}$ induces apoptosis via CAMKIV/AMPK pathways in HT-29 colon cancer cells," Journal of Agricultural and Food Chemistry, vol. 57, no. 22, pp. 1057310578, 2009.

[127] K. A. Kang, M. J. Piao, K. C. Kim et al., "Compound K, a metabolite of ginseng saponin, inhibits colorectal cancer cell growth and induces apoptosis through inhibition of histone deacetylase activity," International Journal of Oncology, vol. 43, no. 6, pp. 1907-1914, 2013.

[128] U. Dougherty, R. Mustafi, Y. Wang et al., "American ginseng suppresses Western diet-promoted tumorigenesis in model of inflammation-associated colon cancer: role of EGFR," BMC Complementary and Alternative Medicine, vol. 11, article 111, 2011.

[129] J. A. Hwang, M. K. Hwang, Y. Jang et al., "20-O- $\beta$-d-glucopyranosyl-20(S)-protopanaxadiol, a metabolite of ginseng, 
inhibits colon cancer growth by targeting TRPC channelmediated calcium influx," Journal of Nutritional Biochemistry, vol. 24, no. 6, pp. 1096-1104, 2013.

[130] S.-H. Jung, M.-S. Woo, S.-Y. Kim et al., "Ginseng saponin metabolite suppresses phorbol ester-induced matrix metalloproteinase- 9 expression through inhibition of activator protein1 and mitogen-activated protein kinase signaling pathways in human astroglioma cells," International Journal of Cancer, vol. 118, no. 2, pp. 490-497, 2006.

[131] Y. Ming, Z. Chen, L. Chen et al., "Ginsenoside compound $\mathrm{K}$ attenuates metastatic growth of hepatocellular carcinoma, which is associated with the translocation of nuclear factor$\kappa \mathrm{B}$ p65 and reduction of matrix metalloproteinase-2/9," Planta Medica, vol. 77, no. 5, pp. 428-433, 2011.

[132] K.-O. Shin, C.-H. Seo, H.-H. Cho et al., "Ginsenoside compound $\mathrm{K}$ inhibits angiogenesis via regulation of sphingosine kinase-1 in human umbilical vein endothelial cells," Archives of Pharmacal Research, vol. 37, no. 9, pp. 1183-1192, 2014.

[133] H. Hasegawa and M. Uchiyama, "Antimetastatic efficacy of orally administered ginsenoside $\mathrm{Rbl}$ in dependence on intestinal bacterial hydrolyzing potential and significance of treatment with an active bacterial metabolite," Planta Medica, vol. 64, no. 8, pp. 696-700, 1998.

[134] S.-J. Lee, J.-H. Sung, S.-J. Lee, C.-K. Moon, and B.-H. Lee, "Antitumor activity of a novel ginseng saponin metabolite in human pulmonary adenocarcinoma cells resistant to cisplatin," Cancer Letters, vol. 144, no. 1, pp. 39-43, 1999.

[135] S. Chae, K. A. Kang, W. Y. Chang et al., "Effect of compound K, a metabolite of ginseng saponin, combined with $\gamma$-ray radiation in human lung cancer cells in vitro and in vivo," Journal of Agricultural and Food Chemistry, vol. 57, no. 13, pp. 5777-5782, 2009.

[136] Y. Chen, P. Wang, H. Liang, S. Liu, L. Mu, and Y. Zhao, "Therapeutic window alteration of irinotecan by ginsenosides," Latin American Journal of Pharmacy, vol. 33, no. 10, pp. 17311734, 2014.

[137] D. G. Lee, S.-I. Jang, Y.-R. Kim et al., "Anti-proliferative effects of ginsenosides extracted from mountain ginseng on lung cancer," Chinese Journal of Integrative Medicine, 2014.

[138] K. W. Leung, L. W. T. Cheung, Y. L. Pon et al., "Ginsenoside $\mathrm{Rb} 1$ inhibits tube-like structure formation of endothelial cells by regulating pigment epithelium-derived factor through the oestrogen $\beta$ receptor," British Journal of Pharmacology, vol. 152, no. 2, pp. 207-215, 2007.

[139] Q. H. Zhang, C. F. Wu, J. Y. Yang, Y. H. Mu, X. X. Chen, and Y. Q. Zhao, "Reduction of cyclophosphamide-induced DNA damage and apoptosis effects of ginsenoside Rbl on mouse bone marrow cells and peripheral blood leukocytes," Environmental Toxicology and Pharmacology, vol. 27, no. 3, pp. 384-389, 2009.

[140] Y. Wang, X. Ye, Z. Ma et al., "Induction of cytochrome P450 1A1 expression by ginsenoside Rg1 and Rb1 in HepG2 cells," European Journal of Pharmacology, vol. 601, no. 1-3, pp. 73-78, 2008.

[141] J. Fujimoto, H. Sakaguchi, I. Aoki, H. Toyoki, S. Khatun, and T. Tamaya, "Inhibitory effect of ginsenoside-Rb2 on invasiveness of uterine endometrial cancer cells to the basement membrane," European Journal of Gynaecological Oncology, vol. 22, no. 5, pp. 339-341, 2001.

[142] K.-S. Kang, B.-C. Kang, B.-J. Lee et al., "Preventive effect of epicatechin and ginsenoside $\mathrm{Rb}_{2}$ on the inhibition of gap junctional intercellular communication by TPA and $\mathrm{H}_{2} \mathrm{O}_{2}$," Cancer Letters, vol. 152, no. 1, pp. 97-106, 2000.
[143] J.-T. Xie, G.-J. Du, E. McEntee et al., "Effects of triterpenoid glycosides from fresh ginseng berry on SW480 human colorectal cancer cell line," Cancer Research and Treatment, vol. 43, no. 1, pp. 49-55, 2011.

[144] F. He, Y. Ding, C. Liang et al., "Antitumor effects of dammaranetype saponins from steamed notoginseng," Pharmacognosy Magazine, vol. 10, no. 39, pp. 314-317, 2014.

[145] H.-H. Aung, S.-R. Mehendale, C.-Z. Wang, J.-T. Xie, E. McEntee, and C.-S. Yuan, "Cisplatin's tumoricidal effect on human breast carcinoma MCF-7 cells was not attenuated by American ginseng," Cancer Chemotherapy and Pharmacology, vol. 59, no. 3, pp. 369-374, 2007.

[146] M. Hao, L. Zhang, Y. Zheng, C. Song, Y. Zhou, and X. Cong, "Anti-proliferative effects of protopanaxadiol-type ginsenosides on human colon epithelial cancer cells," Journal of Chemical and Pharmaceutical Research, vol. 5, no. 12, pp. 141-144, 2013.

[147] L. Berek, D. Szabó, I. B. Petri, Y. Shoyama, Y.-H. Lin, and J. Molnár, "Effects of naturally occurring glucosides, solasodine glucosides, ginsenosides and parishin derivatives on multidrug resistance of lymphoma cells and leukocyte functions," In Vivo, vol. 15, no. 2, pp. 151-156, 2001.

[148] T.-L. Chang, H.-Y. Ding, and Y.-W. Kao, "Role of ginsenoside Rd in inhibiting 26S proteasome activity," Journal of Agricultural and Food Chemistry, vol. 56, no. 24, pp. 12011-12015, 2008.

[149] S. Y. Lee, G. T. Kim, S. H. Roh et al., "Proteome changes related to the anti-cancer activity of HT29 cells by the treatment of ginsenoside Rd," Pharmazie, vol. 64, no. 4, pp. 242-247, 2009.

[150] T. T. Mai, J. Moon, Y. Song et al., "Ginsenoside F2 induces apoptosis accompanied by protective autophagy in breast cancer stem cells," Cancer Letters, vol. 321, no. 2, pp. 144-153, 2012.

[151] J. Y. Shin, J. M. Lee, H. S. Shin et al., "Anti-cancer effect of ginsenoside F2 against glioblastoma multiforme in xenograft model in SD rats," Journal of Ginseng Research, vol. 36, no. 1, pp. 86-92, 2012.

[152] Y. Han, B. Sun, X. Hu et al., "Transformation of bioactive compounds by Fusarium sacchari fungus isolated from the soilcultivated ginseng," Journal of Agricultural and Food Chemistry, vol. 55, no. 23, pp. 9373-9379, 2007.

[153] N. H. Tung, G. Y. Song, C. Van Minh et al., "Steamed ginsengleaf components enhance cytotoxic effects on human leukemia HL-60 cells," Chemical and Pharmaceutical Bulletin, vol. 58, no. 8, pp. 1111-1115, 2010.

[154] W.-J. Shangguan, H. Li, and Y.-H. Zhang, "Induction of G2/M phase cell cycle arrest and apoptosis by ginsenoside Rf in human osteosarcoma MG-63 cells through the mitochondrial pathway," Oncology Reports, vol. 31, no. 1, pp. 305-313, 2014.

[155] T.-L. Chang, Y.-H. Huang, and Y.-D. Ou, "The role of ginsenosides in inhibiting ubiquitin activating enzyme (E1) activity," Journal of Functional Foods, vol. 7, no. 1, pp. 462-470, 2014.

[156] H.-N. Wang, G.-W. Zuo, C.-L. Li et al., "Effects of ginsenoside Rb1, Rg1 on proliferation of leukemia K562 cells," Journal of Clinical Rehabilitative Tissue Engineering Research, vol. 13, no. 40, pp. 7829-7832, 2009.

[157] J. Xia, J. Li, G.-W. Zuo et al., "The effect of ginsenoside Rg1 on EPOR pathway in leukemia cell line TF-1," Tumor, vol. 34, no. 2, pp. 113-120, 2014.

[158] Z.-H. Fan, K. Isobe, K. Kiuchi, and I. Nakashima, "Enhancement of nitric oxide production from activated macrophages by a purified form of ginsenoside (Rg1)," The American Journal of Chinese Medicine, vol. 23, no. 3-4, pp. 279-287, 1995. 
[159] L.-J. Zhang and E.-F. Zhou, "In vitro and in vivo inhibitory effects of ginsenoside Rgl on proliferation of colon cancer cells," World Chinese Journal of Digestology, vol. 22, no. 30, pp. 45994603, 2014.

[160] L. Li, Y. Wang, B. Qi et al., "Suppression of PMA-induced tumor cell invasion and migration by ginsenoside Rg1 via the inhibition of NF- $\kappa \mathrm{B}$-dependent MMP-9 expression," Oncology Reports, vol. 32, no. 5, pp. 1779-1786, 2014.

[161] M. Yu, X. Yu, D. Guo et al., "Ginsenoside Rg1 attenuates invasion and migration by inhibiting transforming growth factor-betalinduced epithelial to mesenchymal transition in HepG2 cells," Molecular Medicine Reports, vol. 11, no. 4, pp. 3167-3173, 2015.

[162] T.-H. Zhao, "Enhancing effect of ginsenoside Rg1 on LAK cells antitumor activity in vitro," Chinese Journal of Clinical Oncology, vol. 21, no. 1, pp. 48-49, 1994.

[163] Y.-N. Lee, H.-Y. Lee, Y. M. Lee et al., "Involvement of glucocorticoid receptor in the induction of differentiation by ginsenosides in F9 teratocarcinoma cells," The Journal of Steroid Biochemistry and Molecular Biology, vol. 67, no. 2, pp. 105-111, 1998.

[164] J.-H. Yoon, Y.-J. Choi, and S.-G. Lee, "Ginsenoside Rh1 suppresses matrix metalloproteinase-1 expression through inhibition of activator protein-1 and mitogen-activated protein kinase signaling pathway in human hepatocellular carcinoma cells," European Journal of Pharmacology, vol. 679, no. 1-3, pp. 24-33, 2012.

[165] J.-S. Jung, J.-H. Ahn, T.-K. Le, D.-H. Kim, and H.-S. Kim, "Protopanaxatriol ginsenoside Rhl inhibits the expression of matrix metalloproteinases and the in vitro invasion/migration of human astroglioma cells," Neurochemistry International, vol. 63, no. 2, pp. 80-86, 2013.

[166] L. Xu, B. Wang, and J. Gao, "Preliminary studies of notoginsenoside R1-induced differentiation of HL-60 cell lines in vitro," Journal of West China University of Medical Sciences, vol. 22, no. 2, pp. 124-127, 1991.

[167] C.-Z. Wang, J.-T. Xie, B. Zhang et al., "Chemopreventive effects of Panax notoginseng and its major constituents on SW480 human colorectal cancer cells," International Journal of Oncology, vol. 31, no. 5, pp. 1149-1156, 2007.

[168] D. G. Popovich and D. D. Kitts, "Ginsenosides 20(S)-protopanaxadiol and Rh2 reduce cell proliferation and increase sub$\mathrm{G}_{1}$ cells in two cultured intestinal cell lines, Int-407 and Caco-2," Canadian Journal of Physiology and Pharmacology, vol. 82, no. 3, pp. 183-190, 2004.

[169] H. Hasegawa, R. Suzuki, T. Nagaoka, Y. Tezuka, S. Kadota, and I. Saiki, "Prevention of growth and metastasis of murine melanoma through enhanced natural-killer cytotoxicity by fatty acid-conjugate of protopanaxatriol," Biological and Pharmaceutical Bulletin, vol. 25, no. 7, pp. 861-866, 2002.

[170] H. Hasegawa, J.-H. Sung, S. Matsumiya et al., "Reversal of daunomycin and vinblastine resistance in multidrug-resistant P388 leukemia in vitro through enhanced cytotoxicity by triterpenoids," Planta Medica, vol. 61, no. 5, pp. 409-413, 1995.

[171] Y. Sun, H. Lin, Y. Zhu et al., "A randomized, prospective, multicentre clinical trial of NP regimen (vinorelbine+cisplatin) plus Gensing Rg3 in the treatment of advanced non-small cell lung cancer patients," Chinese Journal of Lung Cancer, vol. 9, no. 3, pp. 254-258, 2006.

[172] Z.-J. Chen, J. Cheng, Y.-P. Huang et al., "Effect of adjuvant chemotherapy of ginsenoside $\mathrm{Rg} 3$ combined with mitomycin $\mathrm{C}$ and tegafur in advanced gastric cancer," Zhonghua Wei Chang Wai Ke Za Zhi, vol. 10, no. 1, pp. 64-66, 2007.
[173] J.-Y. Huang, Y. Sun, Q.-X. Fan, and Y.-Q. Zhang, "Efficacy of Shenyi Capsule combined with gemcitabine plus cisplatin in treatment of advanced esophageal cancer: a randomized controlled trial," Zhong Xi Yi Jie He Xue Bao, vol. 7, no. 11, pp. 10471051, 2009.

[174] Y. Yu, C. Zhang, L. Liu, and X. Li, "Hepatic arterial administration of ginsenoside $\mathrm{Rg} 3$ and transcatheter arterial embolization for the treatment of VX2 liver carcinomas," Experimental and Therapeutic Medicine, vol. 5, no. 3, pp. 761-766, 2013.

[175] Q. Zhang, X. Kang, B. Yang, J. Wang, and F. Yang, "Antiangiogenic effect of capecitabine combined with ginsenoside $\mathrm{Rg} 3$ on breast cancer in mice," Cancer Biotherapy and Radiopharmaceuticals, vol. 23, no. 5, pp. 647-653, 2008.

[176] X. Huang, M. Hou, C. Yi, and H. Song, "Anti-angiogenic effects of low-dose gemcitabine combined with ginsenoside $\mathrm{Rg} 3$ on mouse Lewis lung carcinoma," Chinese Journal of Lung Cancer, vol. 9, no. 2, pp. 132-136, 2006.

[177] J. Cathcart, A. Pulkoski-Gross, and J. Cao, "Targeting matrix metalloproteinases in cancer: bringing new life to old ideas," Genes \& Diseases, vol. 2, no. 1, pp. 26-34, 2015.

[178] Y.-J. Kim, W.-I. Choi, B.-N. Jeon et al., "Stereospecific effects of ginsenoside 20-Rg3 inhibits TGF-betal-induced epithelialmesenchymal transition and suppresses lung cancer migration, invasion and anoikis resistance," Toxicology, vol. 322, pp. 23-33, 2014.

[179] S. G. Lee, Y. J. Kang, and J.-O. Nam, "Anti-metastasis effects of ginsenoside Rg3 in B16F10 cells," Journal of Microbiology and Biotechnology, vol. 25, no. 12, pp. 1997-2006, 2015.

[180] N. Guan, X. Huo, Z. Zhang, S. Zhang, J. Luo, and W. Guo, "Ginsenoside Rh2 inhibits metastasis of glioblastoma multiforme through Akt-regulated MMP13," Tumor Biology, vol. 36, no. 9, pp. 6789-6795, 2015.

[181] B. Zhou, J. Wang, and Z. Yan, "Ginsenoside Rg3 attenuates hepatoma VEGF overexpression after hepatic artery embolization in an orthotopic transplantation hepatocellular carcinoma rat model," OncoTargets and Therapy, vol. 7, pp. 1945-1954, 2014.

[182] R. Wang, Y. Li, W. Wang, M. Zhou, and Z. Cao, “Compound K suppresses myeloid-derived suppressor cells in a mouse model bearing CT26 colorectal cancer xenograft," Journal of Southern Medical University, vol. 35, no. 5, pp. 748-752, 2015.

[183] Y. Hao, P. Wang, J. Wu, and Q.-Y. Qiu, "Effects of ginsenoside and berberine on secretion of immunosuppressive cytokines in lung carcinoma cell line PG," Zhong Xi Yi Jie He Xue Bao, vol. 6, no. 3, pp. 278-282, 2008.

[184] W. Zhou, M.-Q. Feng, X.-W. Li et al., "X-ray structure investigation of (20S)-20-O- $\beta$-D-glucopyranosyl-protopanaxadiol and antitumor effect on Lewis lung carcinoma in vivo," Chemistry \& Biodiversity, vol. 6, pp. 380-388, 2009.

[185] H. Hasegawa and I. Saiki, "Oleoyl triterpene glycoside biotransformed from ginseng suppresses growth and metastasis of murine B16-F10 melanoma via immunostimulation," Wakan Iyakugaku Zasshi, vol. 17, no. 5, pp. 186-193, 2000.

[186] I. Mellman and R.-M. Steinman, "Dendritic cells: specialized and regulated antigen processing machines," Cell, vol. 106, no. 3, pp. 255-258, 2001.

[187] M. Takei, E. Tachikawa, and A. Umeyama, "Dendritic cells promoted by ginseng saponins drive a potent Thl polarization," Biomarker Insights, vol. 3, pp. 269-286, 2008.

[188] M. Takei, E. Tachikawa, H. Hasegawa, and J.-J. Lee, “Dendritic cells maturation promoted by M1 and M4, end products of steroidal ginseng saponins metabolized in digestive tracts, drive 
a potent Th1 polarization," Biochemical Pharmacology, vol. 68, no. 3, pp. 441-452, 2004.

[189] A. Y. Jang, E. J. Song, S. H. Shin et al., "Potentiation of natural killer (NK) cell activity by methanol extract of cultured cambial meristematic cells of wild ginseng and its mechanism," Life Sciences, vol. 135, pp. 138-146, 2015.

[190] J. Li, T. Liu, L. Zhao et al., "Ginsenoside 20(S)Rg3 inhibits the Warburg effect through STAT3 pathways in ovarian cancer cells," International Journal of Oncology, vol. 46, no. 2, pp. 775781, 2015.

[191] Y.-M. Jeong, W.-K. Oh, T.-L. Tran et al., "Aglycone of Rh4 inhibits melanin synthesis in B16 melanoma cells: possible involvement of the protein kinase A pathway," Bioscience, Biotechnology, and Biochemistry, vol. 77, no. 1, pp. 119-125, 2013.

[192] E. Chung, K.-Y. Lee, Y.-J. Lee, Y.-H. Lee, and S.-K. Lee, “Ginsenoside- $\mathrm{Rg}_{1}$ down-regulates glucocorticoid receptor and displays synergistic effects with cAMP," Steroids, vol. 63, no. 7-8, pp. 421-424, 1998.

[193] H.-D. Yuan, H.-Y. Quan, Y. Zhang, S.-H. Kim, and S.-H. Chung, "20(S)-Ginsenoside Rg3-induced apoptosis in HT-29 colon cancer cells is associated with AMPK signaling pathway," Molecular Medicine Reports, vol. 3, no. 5, pp. 825-831, 2010.

[194] X. Dolcet, D. Llobet, J. Pallares, and X. Matias-Guiu, "NF- $\kappa$ B in development and progression of human cancer," Virchows Archiv, vol. 446, no. 5, pp. 475-482, 2005.

[195] J.-Y. Lee, J.-W. Shin, K.-S. Chun et al., "Antitumor promotional effects of a novel intestinal bacterial metabolite (IH-901) derived from the protopanaxadiol-type ginsenosides in mouse skin," Carcinogenesis, vol. 26, no. 2, pp. 359-367, 2005.

[196] T.-K. Yun, S.-H. Kim, and Y.-S. Lee, “Trial of a new mediumterm model using benzo(a)pyrene induced lung tumor in newborn mice," Anticancer Research, vol. 15, no. 3, pp. 839-845, 1995.

[197] H. Hasegawa and Y. Benno, "Anticarcinogenesis in mice by ginseng-hydrolyzing colonic bacteria," Microbial Ecology in Health and Disease, vol. 12, no. 2, pp. 85-91, 2000.

[198] L.-S. Lee, K.-K. Stephenson, J.-W. Fahey et al., "Induction of chemoprotective phase 2 enzymes by ginseng and its components," Planta Medica, vol. 75, pp. 1129-1133, 2009.

[199] C.-H. Choi, G. Kang, and Y.-D. Min, "Reversal of P-glycoprotein-mediated multidrug resistance by protopanaxatriol ginsenosides from korean red ginseng," Planta Medica, vol. 69, no. 3, pp. 235-240, 2003.

[200] S. Kitagawa, T. Takahashi, T. Nabekura, E. Tachikawa, and H. Hasegawa, "Inhibitory effects of ginsenosides and their hydrolyzed metabolites on daunorubicin transport in KB-C2 cells," Biological \& Pharmaceutical Bulletin, vol. 30, no. 10, pp. 1979-1981, 2007. 


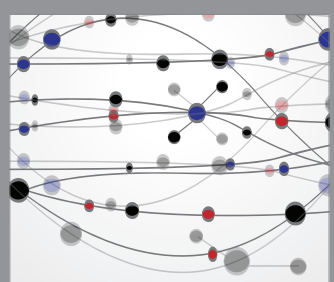

The Scientific World Journal
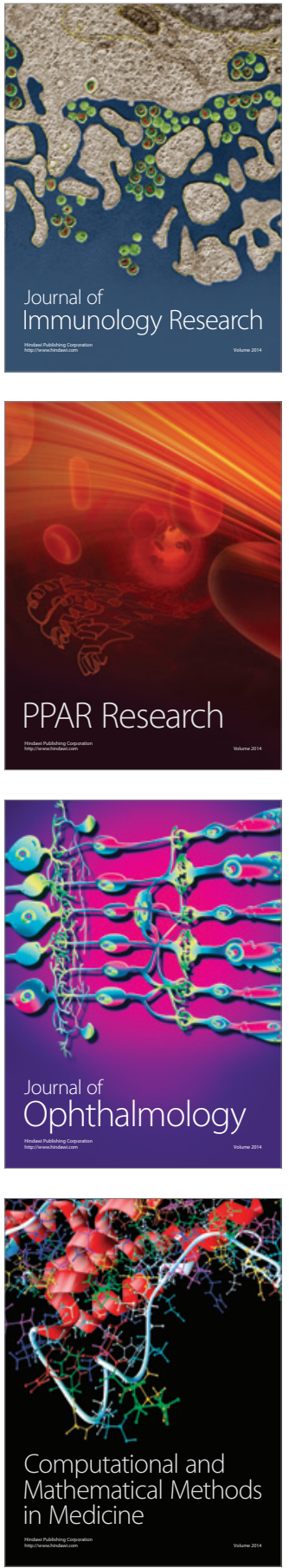

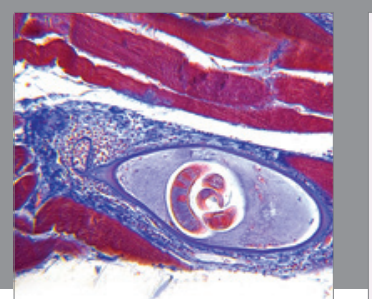

Gastroenterology Research and Practice

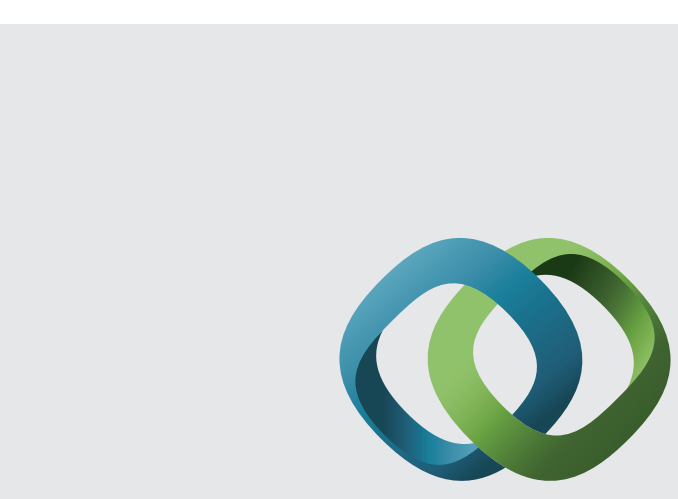

\section{Hindawi}

Submit your manuscripts at

http://www.hindawi.com
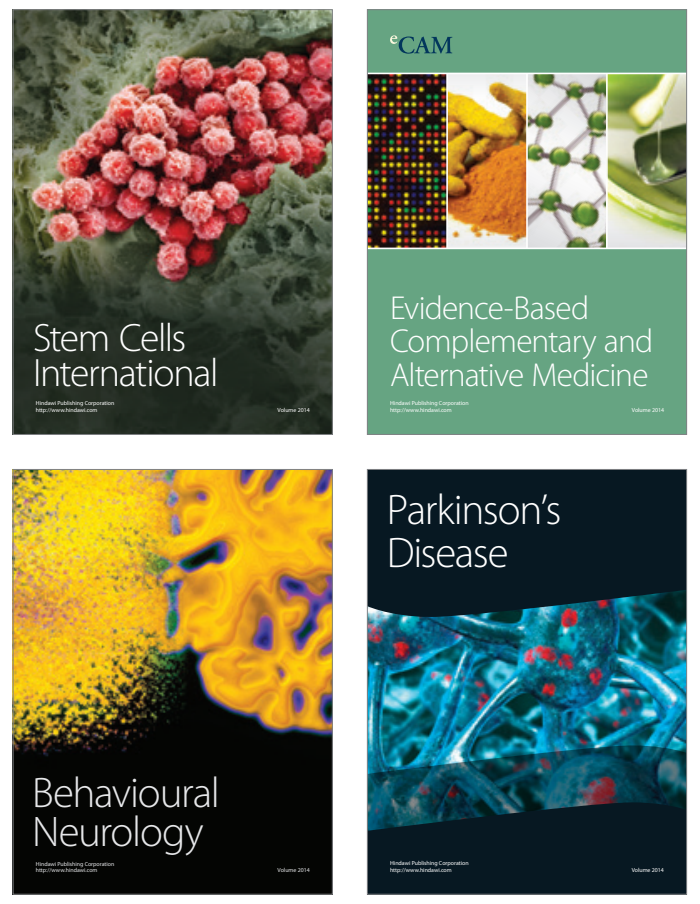
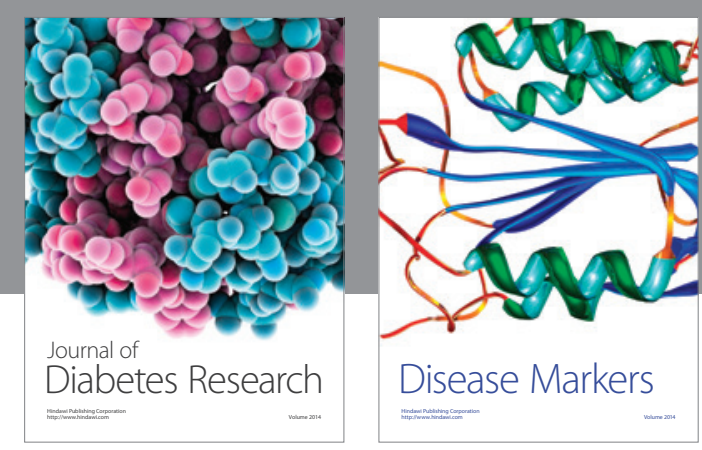

Disease Markers
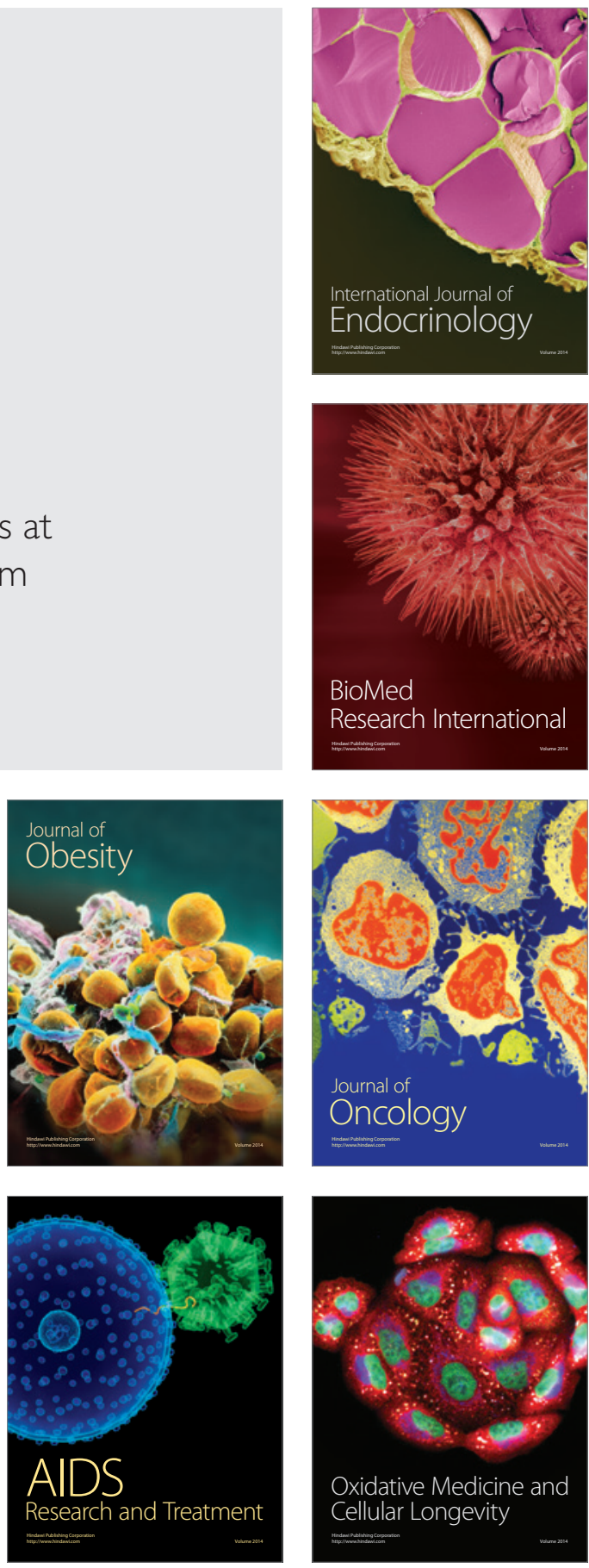